\title{
Traducción de culturemas en textos turísticos: tratamiento en español de las voces que designan la vestimenta tradicional coreana'
}

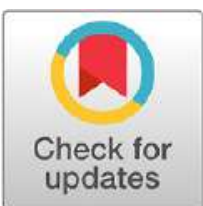

\author{
Sara Robles Ávila \\ sara.robles@uma.es \\ https://orcid.org/0000-0002-2929-647X \\ Universidad de Málaga, España \\ Jin Seo Park \\ pedrogonzalo.park@gmail.com \\ https://orcid.org/0000-0003-0665-936X \\ Universidad de Málaga, España
}

\section{Resumen}

La vestimenta tradicional forma parte del patrimonio de una cultura y es reflejo de su idiosincrasia, su seña de identidad arraigada en la historia. En esta investigación analizamos los culturemas relativos a la indumentaria tradicional de Corea, el hanbok. Tomando como fuente la web turística institucional de promoción del país asiático VisitKorea, hemos obtenido un corpus formado por un total de 18 culturemas. Para llevar a cabo el estudio hemos establecido una lista de técnicas traslativas a nivel microtextual que se emplean en la traducción de estas palabras culturales para hacerlas comprensibles a hablantes de español, tratando de salvar así la enorme distancia lingüística y cultural entre ambas áreas. Nuestro interés se dirige a las unidades oracionales - no solo a las unidades léxicas-, en las cuales se reflejan distintos aspectos culturales en forma de paráfrasis o traducción explicativa. Como resultado del análisis concluimos que las técnicas que se usan con más recurrencia para traducir los culturemas de nuestro corpus son el préstamo, la descripción del aspecto y la descripción de los usuarios. A lo largo de la investigación hemos constatado que, para reducir la enorme brecha lingüístico-cultural entre Corea y los países hispanos, resulta imprescindible el dominio de las habilidades y los conocimientos lingüísticos e interculturales durante la labor de traducción-interpretación, más allá del puro trasvase verbal.

Palabras clave: culturemas; análisis traductológico; técnicas traslativas; vestimenta coreana; textos turísticos.

1 Este artículo forma parte del ámbito de investigación en el que se desarrolla la tesis doctoral que está elaborando Jin Seo Park, titulada "Culturemas gastronómicos coreanos en los textos turísticos: mediación y traducción como estrategias para su comunicación”, cuya directora es la profesora Sara Robles Ávila. La tesis doctoral se inscribe en el programa de doctorado de la Facultad de Filosofía y Letras de la Universidad de Málaga, España, "Lingüística, Literatura y Traducción" (Real Decreto 99/2011). 


\title{
Translating Culturemes in Tourism Texts: How to Treat Words Used to Name Traditional Korean Costumes
}

\begin{abstract}
Traditional clothing is considered a heritage of a given culture or cultural region, and reflects uniquely indigenous cultural values, a sign of identity rooted in history. In this research work, we will analyze some culturemes connected to Korean traditional clothing, called hanbok. Drawing from the website VisitKorea, which promotes this Asian country, we have brought together a corpus of 18 culturemes. To carry out this study, we have listed a number of translation techniques at micro-textual level, which are used to translate these culturemes, so that they are made understandable by Spanish speakers, and bridge the wide linguistic and cultural gap between both cultures. We are focused on sentence units, rather than merely lexical units, which reflect manifold cultural aspects are reflected in the form of paraphrases or explanatory translation. The analysis led us to conclude that the most commonly used techniques to translate culturemes in our corpus are loanwords, looks description and wearer's description. During the course of our research, we could validate that, to reduce the huge linguistic-cultural gap between Korea and Hispanic countries, it turns to be essential to display a good command of linguistic and intercultural knowledge during the translation/interpretation work, rather than a mere verbal transfer.
\end{abstract}

Keywords: culturemes; translation analysis; translation techniques; Korean clothing; tourist texts.

\section{Traduction de culturèmes dans les textes touristiques: traitement en espagnol des voix qui désignent les vêtements traditionnels coréens}

\section{Résumé}

Les vêtements traditionnels font partie du patrimoine d'une culture ou d'une aire culturelle et sont le reflet de son idiosyncrasie, de son identité ancrée dans l'histoire. Dans cette recherche, nous analysons les culturèmes liés au vêtement traditionnel de la Corée, le hanbok. En prenant comme source le site web touristique institutionnel VisitKorea, nous avons obtenu un corpus composé d'un total de 18 culturèmes. Pour mener à bien cette étude, nous avons établi une liste de techniques de traduction au niveau microtextuel qui sont utilisées dans la traduction de ces mots culturels afin de les rendre compréhensibles aux hispanophones, essayant ainsi de combler l'énorme fossé linguistique et culturel entre les deux régions. Nous nous intéressons aux unités de phrase - et pas seulement aux unités lexicales - dans lesquelles différents aspects culturels sont reflétés sous forme de paraphrase ou de traduction explicative. À la suite de cette analyse, nous concluons que les techniques les plus fréquemment utilisées pour traduire les culturèmes de notre corpus sont l'emprunt, la description de l'aspect et la description des utilisateurs. Tout au long de la recherche, nous avons constaté que, pour réduire l'énorme fossé linguistique et culturel entre la Corée et les pays hispaniques, il est essentiel de maîtriser les compétences et les connaissances linguistiques et interculturelles pendant le travail de traduction-interprétation, au-delà du pur transfert verbal.

Mots clefs : culturèmes ; analyse traductologique ; tecniques de traduction ; vetements coréens ; textes touristiques. 


\section{Tradición, vestimenta y culturemas: el hanbok coreano}

A pesar de que las huellas de la globalización se dejan ver de manera palpable en la jerga del turismo, con la difusión de voces generalmente en inglés, que ha conformado lo que Calvi (2006, pp. 11-12) denomina "núcleo duro terminológico" de esta área de especialidad, cada lengua y cada cultura preservan un conjunto de elementos léxicos particulares propios que representan objetos tangibles o realidades inmateriales, muestras de su idiosincrasia, su tradición, su historia y su proceder social asentados con el paso del tiempo. Son los culturemas o palabras culturales los elementos que muestran con mayor exactitud y de manera más apreciable la relación entre cultura y lengua, ya que representan verbalmente la tradición de una comunidad determinada en un espacio concreto. Estas voces constituyen uno de los aspectos más exóticos del lenguaje del turismo, que se diseminan en sus distintos ámbitos o sectores - los alojamientos, la gastronomía, las tradiciones, etc. - . En este contexto, la vestimenta tradicional exclusiva de un determinado destino turístico - más aún si se muestra distante del público receptor- desempeña un papel trascendental en las manifestaciones de su valor cultural, pues recoge la idiosincrasia de la cultura, sus hábitos y costumbres más arraigados y su diferenciación.

La indumentaria, más allá de ser un elemento imprescindible para la supervivencia humana, forma parte del patrimonio cultural inmaterial $^{2}$ de una región y es reflejo de la diversidad

2 Entre los bienes inscritos en la Lista del Patrimonio Cultural Inmaterial de la UNEsCo se consigna un nutrido volumen de elementos relativos a los propios atuendos u objetos de vestir, tejidos, técnicas de producción o confección, artes textiles pertenecientes en su mayoría a tres de los cinco ámbitos establecidos en 2003 por la Convención para la internacional. La vestimenta representa el resultado de técnicas muchas veces vinculadas a la artesanía, fruto de la creatividad humana y tiene una fuerte carga ritual. Se trata de un elemento profundamente anclado en la historia, fundado en la tradición, entendida esta como la articulación entre pasado y presente, donde se conjugan prácticas pretéritas con el uso actual y permite situar los propios orígenes y dotar de sentido de pertenencia a un grupo o una comunidad (Hernández i Martí, 2005).

Por mostrar las peculiaridades de una cultura, el léxico de la vestimenta se percibe como un área muy fértil para el estudio de culturemas. En Corea del Sur, el llamado hanbok - literalmente "ropa coreana"-, el traje tradicional con todos sus complementos y adornos, expresa la identidad popular de este país pero, a pesar de su hermosura y de su gran valor cultural, es la menos conocida del noreste asiático, comparado con el kimono de Japón y el chipao de China. Este atuendo, usado por hombres, mujeres y niños, con sus respectivas particularidades, se ha ido acomodando de manera dinámica a los estilos de vida, los cambios sociales y a la estética de cada época como "herencia actualizada" (Cruces, 2005). Aun así, ha conservado sus rasgos distintivos en la comunidad durante los casi 5000 años de historia del país, y forma parte de su patrimonio inmaterial. Dicho patrimonio sigue vivo y se adapta a los nuevos tiempos, pues es recreado constantemente por la sociedad coreana, e infunde un sentimiento de hermanamiento y tradición compartida.

El hanbok actual se asocia particularmente al período Choseon, y se usa como ropa semiformal o formal en las festividades más relevantes

Salvaguarda del Patrimonio Cultural Inmaterial: usos sociales, rituales y actos festivos; técnicas artesanales tradicionales y tradiciones y expresiones orales. 
- el Año Nuevo Lunar o el Día de la Acción de Gracias (추석 [chuseok])-, en las ceremonias matrimoniales, en reuniones sociales protocolarias. Actualmente es empleado también entre los jóvenes coreanos para pasear por zonas monumentales del país y fotografiarse (Park et al., 2019). Asimismo, hoy día existen programas turísticos en los que se invita a los visitantes foráneos a vestir este atuendo típico tradicional.

Grosso modo, el hanbok de mujer está compuesto por un jeogori, una blusa o chaqueta con mangas amplias, y una falda larga envolvente llamada chima. Lleva una cinta que acentúa la línea del busto. Muchos incluyen bordados que añaden elegancia al vestido. Así el conjunto del traje femenino es a menudo llamado jeogori-chima. El hanbok tradicional de los varones está formado también por un jeogori (camisa o chaquetilla) y unos pantalones holgados llamados baji. A estas prendas se añade toda una serie de complementos que forman parte de nuestro corpus de estudio.

Las constantes referencias en los textos turísticos a los atuendos, los complementos, las formas de llevarlos, etc. nos exigen enfrentarnos a la complejidad que supone su tratamiento traductológico. Así, pues, nuestra propuesta consistirá en el análisis del trasvase del coreano al español de estos culturemas de la vestimenta tradicional coreana, a fin de identificar cuáles son las técnicas traslativas más empleadas en los textos turísticos para llevar a cabo los procesos de traducción-interpretación.

\section{El culturema: delimitación conceptual y técnicas traslativas para su tratamiento traductológico}

El culturema se define, según Vermeer (citado por Nord, 2007), como "un fenómeno social de una cultura $\mathrm{X}$ que es entendido como relevante por los miembros de esa cultura y que, comparado con un fenómeno correspondiente de una cultura $\mathrm{Y}$, es percibido como específico de la cultura X" (traducción de Hurtado Albir, 2018, p. 611). Existen divergencias sobre el origen del término culturema: Luque $\mathrm{Na}$ dal (2009, p. 95) lo atribuye a distintos autores como Christiane Nord, Els Oksaar o Hans Vermeer, mientras que Eun Hee Kwon (2009, p. 427) reconoce su autoría a Michael Agar, y Hurtado Albir (2018, p. 611) considera que fue Vermeer quien propuso este término, basado en la Kulturemtheorie (1958), formulada por Oksaar.

En principio podría parecer que los culturemas se refieren únicamente a los fenómenos culturales de una comunidad; sin embargo, estos referentes culturales incluyen una amplia variedad de elementos, tal como señala Nord (1994, p. 524): verbales, no-verbales, paraverbales o la combinación de estos tres. En nuestra opinión, el culturema es fruto de la íntima e indisociable relación entre lengua y cultura, que se refleja en unidades tanto léxicas como fraseológicas. Por esta razón es lógico que haya sido estudiado principalmente desde el ámbito de la traducción.

El lingüista Eugene Nida (1945) destacó la importancia de los elementos culturales en la traducción bíblica y llamó la atención sobre la estrecha relación entre cultura y lengua. Medio siglo después, también Stolze (2011, p. 97) señaló que en el contexto cultural interviene de manera decisiva la lengua y, del mismo modo, las producciones lingüísticas de los hablantes logran adquirir su sentido dentro del contexto cultural en el que se emplean. En consecuencia, es evidente que el hecho de transferir elementos verbales de una lengua a otra no es en absoluto automático ni simple, por lo que llevan aparejado de componente cultural y contexto de uso. De ello se colige que comprender y saber 
interpretar los hechos culturales y los fenómenos lingüísticos es una tarea imprescindible en la labor de traducción.

Particularmente, los funcionalistas otorgan especial relevancia a los elementos culturales en la traducción (Stolze, 2011, pp. 195-199; Kim, 2016, pp. 64-65; Hurtado Albir, 2018, p. 608). En este contexto, se ha comprobado la superioridad de la equivalencia dinámica - también llamada equivalencia funcional - respecto de la correspondencia formal (Waard y Nida, 1986, p. 36), o traducción literal, palabra por palabra (Roberts, 1974, pp. 8-9). Hatim y Mason (1995) definen la equivalencia dinámica como el "principio de equivalencia de efecto en el lector de la versión" (p. 17), entendiendo por tal la búsqueda de la equivalencia más exacta entre el elemento cultural de la lengua de partida y otro elemento correspondiente en la lengua meta. Con la equivalencia dinámica en la traducción bíblica se pretendía que hasta los lectores legos en la lengua de origen pudieran alcanzar el nivel de comprensión de los lectores de las biblias originales ${ }^{3}$ (Marlowe, 2012), para lo cual utilizaron todas las técnicas y procedimientos lingüísticos disponibles. Sirva como ejemplo el referente aloe, que aparece en San Juan 19:39. ${ }^{4}$ En las biblias

3 En la iglesia protestante se utilizan distintos tipos de biblias que adoptan estos dos enfoques. Las biblias en inglés basadas en la equivalencia dinámica son $N e w$ International Version (NIV), New English Translation (NET), Common English Bible (CEB), etc. La biblia más representativa de la correspondencia formal es King James Version (KJv). En español, Dios Habla Hoy (DHH), Nueva Versión Internacional (NVI), Palabra de Dios para Todos (PDT), Traducción en lenguaje actual (TLA), entre otras, se basan en la equivalencia dinámi$\mathrm{Ca}$, mientras que la versión Reina-Valera (RVA), sigue los presupuestos de la correspondencia formal al ser la primera versión bíblica protestante en castellano.

4 Reina-Valera ("También Nicodemo, el que antes había visitado a Jesús de noche, vino trayendo un compuesto de mirra y de áloes, como cien libras"). en Corea del Sur, el referente aloe se tradujo como 침향 [chimhyang], cuyo nombre científico es Aquilariae Lignum, y que no tiene nada que ver con el aloe de la biblia original. Cuando se tradujo la biblia al coreano no existía este vegetal en este país asiático, razón por la cual se habría adoptado este referente conocido en la cultura coreana. En consecuencia, en la actualidad sería necesario cambiar chimhyang por aloe, dado que este último ya es un referente común en la Corea actual.

En nuestro caso, el trasvase de una lengua a otra de estos culturemas para designar atuendos tradicionales que han sobrevivido al paso del tiempo - aunque hoy están relegados a usos específicos- supone un auténtico escollo en la tarea de traducción por la dificultad de adecuación entre el culturema y el elemento que lo represente en la lengua meta. Aquí coincidimos con Newmark (2010, p. 133) en que los elementos culturales siempre generan problemas en la traducción, especialmente si no hay acomodo cultural entre las dos lenguas en juego, es decir, si no comparten una base cultural común. Esa dificultad se acrecienta porque no se ha llegado a un consenso con respecto a la representación terminológica de estos elementos culturales.

En este punto conviene hacer una distinción entre lo referido - el referente o la realidad extralingüística - y la referencia -el signo lingüístico-, tal como propugnan autores como Nord, Mayoral Asensio, Cartagena, etc. (Mendoza García, 2018, p. 194). Para citar un ejemplo, el trabajo de Mayoral Asensio (1999) constata la diversidad tanto terminológica como conceptual de los elementos culturales. En la Tabla 1, representamos las denominaciones que este autor registra para aplicar tanto a lo referido - el referente - como al signo lingüístico - la referencia-

Aparte de estas denominaciones, existen otras como culture-specific items (Aixelá, 1996) 
Tabla 1. Denominaciones terminológicas según la referencia y el referente.

\begin{tabular}{|c|c|}
\hline Referente & Referencia \\
\hline $\begin{array}{l}\text { Referencias culturales } \\
\text { (Escuela de Granada) }\end{array}$ & $\begin{array}{l}\text { Segmentos marcados } \\
\text { culturalmente (Mayoral } \\
\text { Asensio) }\end{array}$ \\
\hline Culturemas (Nord) & $\begin{array}{l}\text { Referencias culturales } \\
\text { (Escuela de Granada) }\end{array}$ \\
\hline $\begin{array}{l}\text { Realias culturales } \\
\text { (Escuela Soviética/Eslava } \\
\text { y de Leipzig) }\end{array}$ & $\begin{array}{l}\text { Palabras-realias (Escuela } \\
\text { Eslava y de Leipzig) }\end{array}$ \\
\hline $\begin{array}{l}\text { Presuposiciones (Nida y } \\
\text { Reyburn) }\end{array}$ & $\begin{array}{l}\text { Nombres de referentes } \\
\text { culturales específicos } \\
\text { (Cartagena) }\end{array}$ \\
\hline $\begin{array}{l}\text { Divergencias } \\
\text { metalingüísticas } \\
\text { (Comparativismo) }\end{array}$ & $\begin{array}{l}\text { Indicadores culturales } \\
\text { (Nord) }\end{array}$ \\
\hline \multirow{2}{*}{$\begin{array}{l}\text { Referentes culturales } \\
\text { específicos (Cartagena) }\end{array}$} & $\begin{array}{l}\text { Palabras culturales } \\
\text { (Newmark) }\end{array}$ \\
\hline & $\begin{array}{l}\text { Léxico vinculado a una } \\
\text { cultura (Katan) }\end{array}$ \\
\hline
\end{tabular}

Fuente: Mayoral Asensio (1999)

o lexicultura (Galisson, 1988). Particularmente, Calvi denomina términos culturales a los signos lingüísticos con algún grado de especificidad cultural que aparecen en los textos o el discurso turísticos; y los define como vocablos exclusivos que reflejan la idiosincrasia cultural de una lengua (2018, p. 204) y que, además, no cuentan con equivalentes en la lengua receptora (2006, p. 67). Esta última consideración coincide con Baker (2011, p. 18), que habla de non-equivalence como causa de la dificultad traslativa, aunque la falta de equivalencia no implica necesariamente la intraducibilidad (González-Pastor, 2018, p. 13).

Como nuestro corpus de culturemas procede de textos turísticos, nos resultaría apropiado adoptar la nomenclatura de Calvi, es decir, términos culturales, si bien emplearemos el término culturema, porque más allá de ser una de las denominaciones más utilizadas en el ámbito de la traductología, teniendo en cuenta la consideración de Molina Martínez (2006), “...encontramos acertado recurrir al sufijo '-ema', utilizado por la lingüística, que hace que sea fácilmente inteligible" (p. 77).

No obstante, la cuestión terminológica no es el único problema que plantean las palabras culturales. El punto de partida en la investigación sobre culturemas presenta la dificultad de su discriminación, es decir, la identificación de lo que es propiamente un elemento cultural frente a lo que no lo es. Si sucede que un referente extranjero es importado a otra cultura y a otra lengua de acogida con un nivel de integración absoluto, será difícil reconocer su especificidad cultural foránea. Del ámbito de la vestimenta encontramos los casos de pantalones vaqueros y bikini. Estos atuendos, que originalmente procedían de culturas extranjeras, una vez extendido su uso en los países asiáticos, no mantienen ya la especificidad cultural de su origen; dicho de otro modo, ya son atuendos no marcados culturalmente. A pesar de que en un principio y hasta su difusión internacional estas referencias podrían haber sido culturemas con marcas de su origen, actualmente ya no se pueden considerar referentes con especificidad exótica y singular de un área cultural concreta. Pero también puede ocurrir lo contrario, como sucede con la voz kimono, que designa la túnica tradicional japonesa, y que aparece registrada en el lemario del Diccionario de la lengua española (RAE, 2014) escrita tanto con " $k$ ", como préstamo, en letra redonda; o con "q", más adaptado a la grafía española.

Este caso refleja cómo la introducción de artículos extranjeros en un determinado país o comunidad posibilita la expansión de su uso y, por tanto, el conocimiento y la familiaridad por parte de sus usuarios; pese a ello, esta voz no ha visto mermada su idiosincrasia cultural japonesa, su profunda identidad nacional. Así, pues, mientras que los vaqueros y el bikini no se pueden considerar culturemas en los países asiáticos, el kimono sigue siendo un culturema en los países de habla hispana. 
Otro hecho que dificulta la identificación de culturemas es la inexistencia de una clasificación eficaz de lo cultural. Nida (1945) propuso la siguiente tipología: ecología, cultura material, cultura social, cultura religiosa y cultura lingüística (p. 196). Sin embargo, debemos admitir que está ideada para clasificar conceptos culturales. Más clara nos resulta la clasificación de cultura de Galisson (1988), formulada para delimitar el concepto de lexicultura y muy conocida en el ámbito de la didáctica de las lenguas extranjeras o las segundas lenguas. Según su planteamiento, la cultura se divide en cultura maximalista - también llamada cultura sabia (Galisson, 2000, p. 48) o cultura elitista (Ayuso Collante, 2019, p. 14)- y cultura minimalista (Galisson, 1988, p. 325) —cultura-acción (Galisson, 2000, p. 48) o cultura popular (Le Gall, 2009, p. 179)—. Según Robles Ávila y Park (2021, p. 80), la cultura sabia o maximalista refleja los conocimientos compartidos solo entre grupos elitistas, mientras que la cultura-acción o minimalista hace referencia a los fenómenos culturales que conoce cualquier nativo, independientemente de la clase a la que pertenezca. Otra consideración similar la podemos encontrar en Luque Nadal (2009, p. 97), quien define el culturema como un fenómeno bastante conocido entre los miembros de una comunidad, que se utiliza como elemento comunicativo y expresivo en los intercambios. Teniendo en cuenta estos planteamientos, consideramos que el culturema tiene que ver con la cultura-acción o minimalista; $y$, por lo que respecta a los culturemas de nuestro corpus, la tipología de cultura propuesta por Galisson encaja en nuestro planteamiento, puesto que la vestimenta se incluye en este tipo de cultura y está íntimamente relacionada con la historia, la flora y la fauna, las condiciones climáticas y geográficas y, en definitiva, con la vida cotidiana de los miembros de una sociedad.

Una dificultad más que plantea el trasvase de culturemas es el nivel de correspondencia, el grado de afinidad lingüístico-cultural entre las lenguas que participan en el juego de la traducción. Mayoral Asensio y Muñoz Martín (1997, p. 144) se refieren al grado de correspondencia al proponer segmentos marcados culturalmente, entendiendo que una correspondencia mayor se producirá generalmente entre el léxico de uso común (luna, falda, mesa...), así como entre las lenguas de cultura próxima (italiano, francés, español...). Es el caso, por ejemplo, del referente en español jamón serrano; en Italia, Portugal y Francia existen otros similares: prosciutto, presunto y jambon, respectivamente, considerados sinónimos. Así, al traducir jamón serrano a estas lenguas, nos surge el interrogante de si se trata realmente de culturemas. Entre estas referencias existe un elemento cultural en común, razón por la cual se crea una estrecha correspondencia entre ellas. Todo esto nos permite concluir que la correspondencia de alto grado tiende a ocurrir entre lenguas y culturas afines.

Una vez realizado este breve recorrido por el tratamiento conceptual del culturema y abordadas las que consideramos mayores dificultades para su trasvase de una lengua $\mathrm{X}$ a otra $\mathrm{Y}$, nos centraremos en la determinación de las técnicas traslativas que se emplean en su tratamiento traductológico. Como afirma Hurtado Albir (2018, p. 615), no existen técnicas específicas para la traducción de culturemas. Sin embargo, la propuesta general de técnicas de traducción a nivel microtextual planteada por Molina Martínez y Hurtado Albir (2002, pp. 509-511) nos resulta muy útil por su exhaustividad, ya que identifica 18 técnicas: adaptación, ampliación lingüística, amplificación, calco, compensación, compresión lingüística, creación discursiva, descripción, elisión, equivalente acuñado, generalización, modulación, particularización,

5 La investigación de Molina Martínez y Hurtado Albir (2002) se realiza en inglés; para mayor comprensión citamos la misma propuesta, pero en español (Hurtado Albir, 2018). 
préstamo, sustitución, traducción literal, transposición y variación.

Así pues, para llevar a cabo este estudio, hemos establecido una propuesta de técnicas ad hoc, a partir de la combinación de las técnicas planteadas por Molina Martínez y Hurtado Albir y la incorporación de los segmentos marcados culturalmente de Mayoral Asensio y Muñoz Martín (1997, pp. 148-150). Esta última contempla la amplificación que se realiza dentro del texto traducido mediante una explicación detallada de los rasgos caracterizadores. Aunque la amplificación estaba ya recogida en el repertorio de técnicas de Molina Martínez y Hurtado Albir, la propuesta de Mayoral Asensio y Muñoz Martín pone el foco en los recursos que se emplean para amplificar, es decir, qué rasgo o elemento se destaca del culturema para hacerlo más comprensible para el receptor de la lengua y la cultura metas. Como ejemplo, utilizaron un referente gastronómico, el latkes, y establecieron las siguientes técnicas de amplificación cultural, a saber, a)préstamo + formulación funcional; b) procedimiento de preparación; c) enumeración de ingredientes; d)descripción del aspecto; e)cualidades evocadas; f)valores emotivos, g) históricos, h) culturales, etc. sugeridos o combinaciones de las anteriores.

Al realizar nuestra propuesta de técnicas traslativas, hemos tenido en cuenta la gran distancia lingüístico-cultural entre Corea y los países hispanos, razón por la cual hemos convenido que la traducción de los culturemas de vestimenta tradicional coreana no resulta comprensible cuando se realiza mediante traducciones literales, por lo cual se ha de acudir a otras técnicas más completas y complejas. La especificidad cultural reflejada en los atuendos coreanos resulta tan distante de la cultura hispánica que la traducción explicativa o paráfrasis, los segmentos marcados culturalmente de Mayoral Asensio y Muñoz Martín (1997) — también denominados amplificación o descripción (Molina Martínez y Hurtado Albir, 2002), glosas intratextual y extratextual (Aixelá, 1996), equivalente descriptivo (Newmark 2010), etc.-pueden ser una técnica muy útil para transmitir el sentido cultural auténtico que alberga un culturema. Tras considerar estas características y llevar a cabo una detenida observación de los culturemas que conforman nuestro corpus, hemos establecido las siguientes técnicas, que explicaremos a continuación: a) préstamo, b) particularización, c) generalización, d) equivalente acuñado, e)identificación del usuario, f)descripción del aspecto, g) descripción de la información histórica, h) descripción de los complementos, i)descripción de la producción y j) descripción del uso.

\section{Descripción del corpus de estudio}

El corpus de culturemas correspondiente a la vestimenta tradicional coreana ha sido obtenido de la guía oficial VisitKorea, ${ }^{6}$ publicada por la Organización del Turismo de Corea (en inglés Korea Tourism Organization, KTO), ${ }^{7}$ entidad pública del estado encargada de dar a conocer y promocionar los recursos turísticos del país. ${ }^{8}$ VisitKorea es una guía institucional online que ofrece esta organización a los interesados en viajar al país asiático, muy similar al sitio web de Turespaña. Esta página web ofrece un contenido vasto y muy diversificado, que va desde información general sobre el país asiático hasta presentaciones de atractivos turísticos,

6 https://spanish.visitkorea.or.kr/spa/index.kto

7 https://kto.visitkorea.or.kr/kor.kto

8 Sobre la configuración lingüístico-discursiva de las páginas web institucionales de promoción turística, como el caso que nos ocupa, se pueden ver Robles Ávila (2019a) y (2019b), donde se realiza un estudio detallado de las características de los sitios institucionales, en este caso, de las webs de ciudades patrimonio de la humanidad de España. 


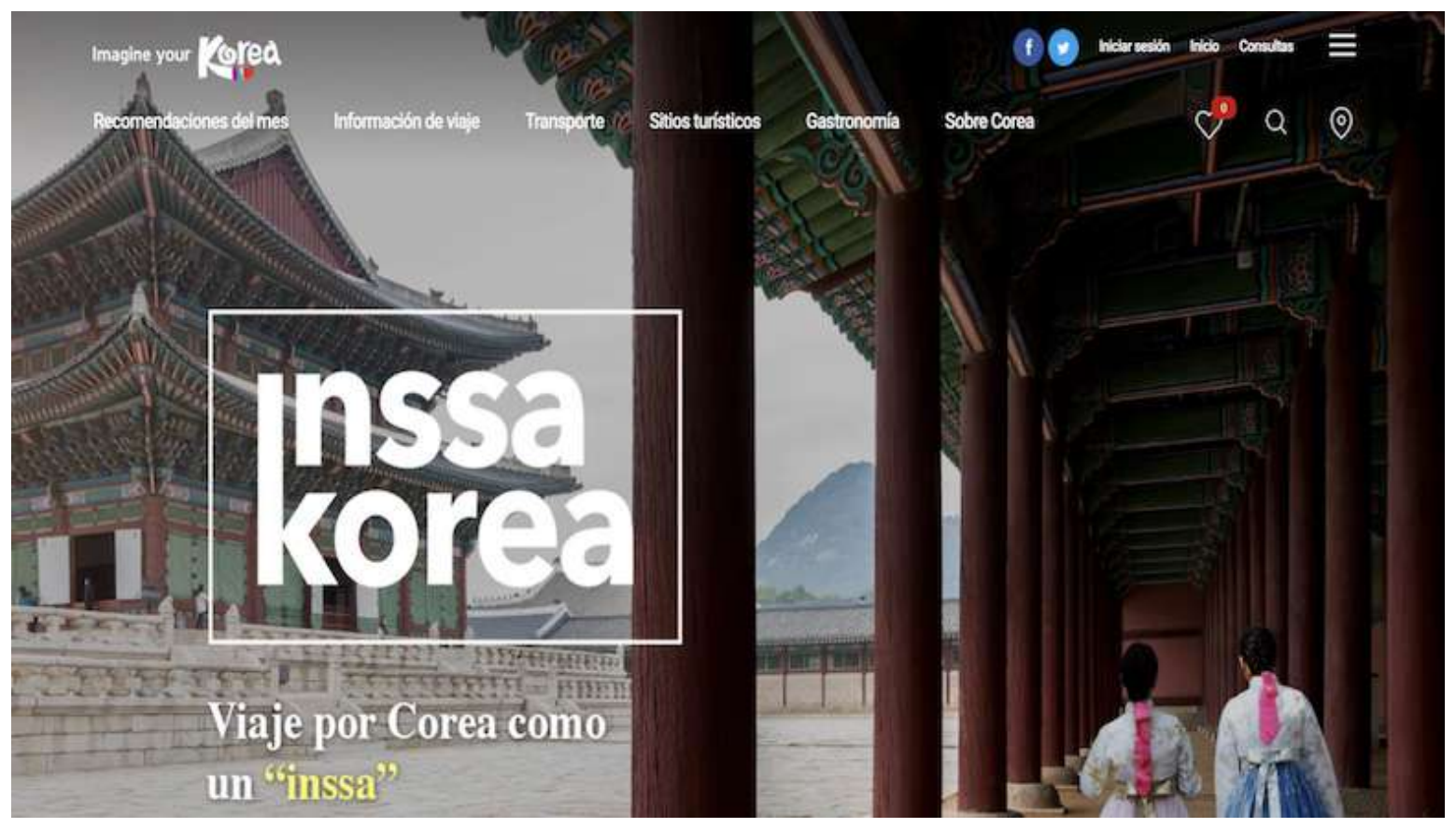

Figura 1. Imagen captada de la portada de VisitKorea. Recuperado de https://spanish.visitkorea.or.kr/spa/ index.kto\#

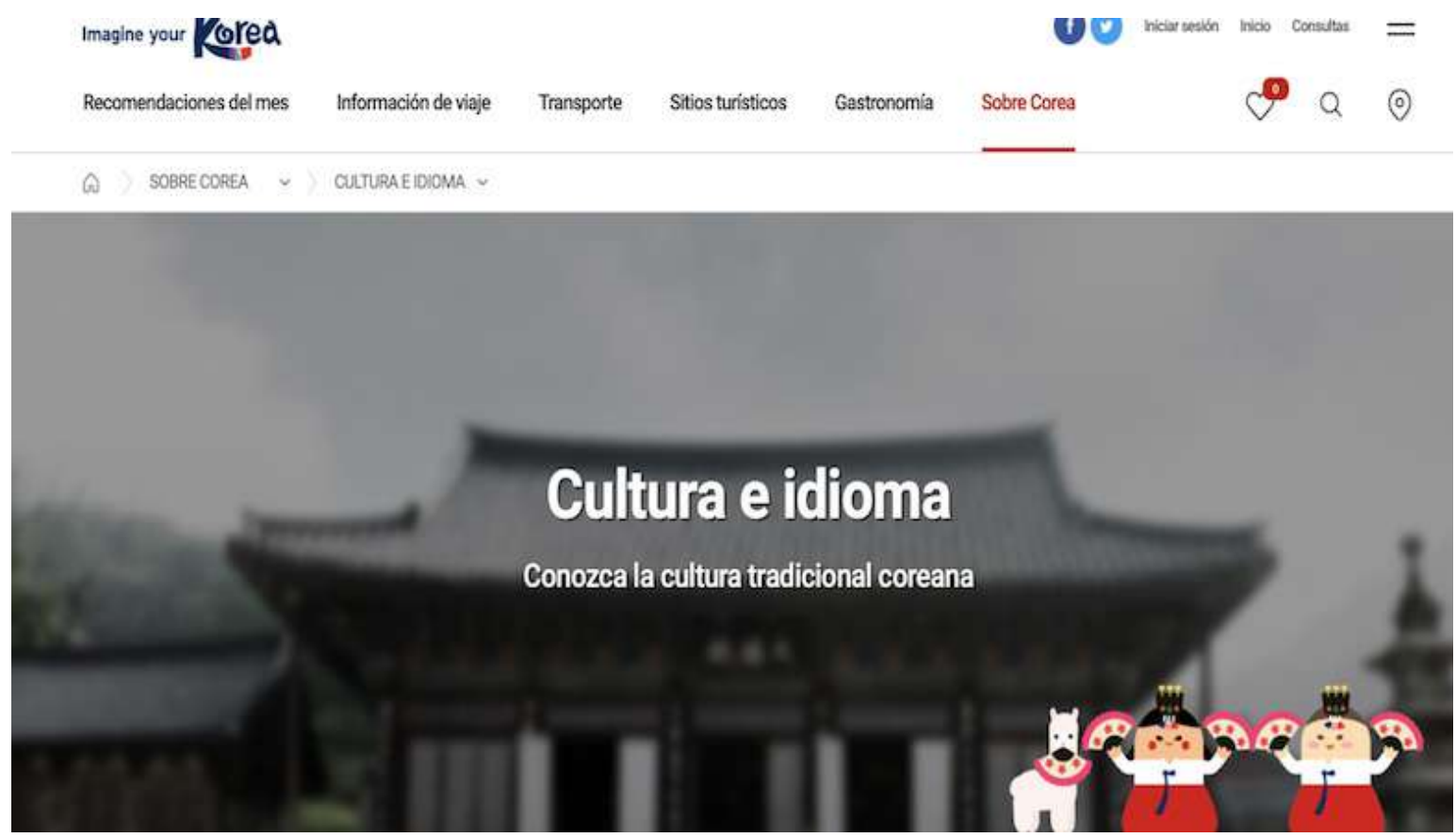

Figura 2. Imagen captada de la sección Cultura e idioma de VisitKorea. Recuperado de https://spanish.visitkorea. or.kr/spa/KOl/6_2_list.kto 

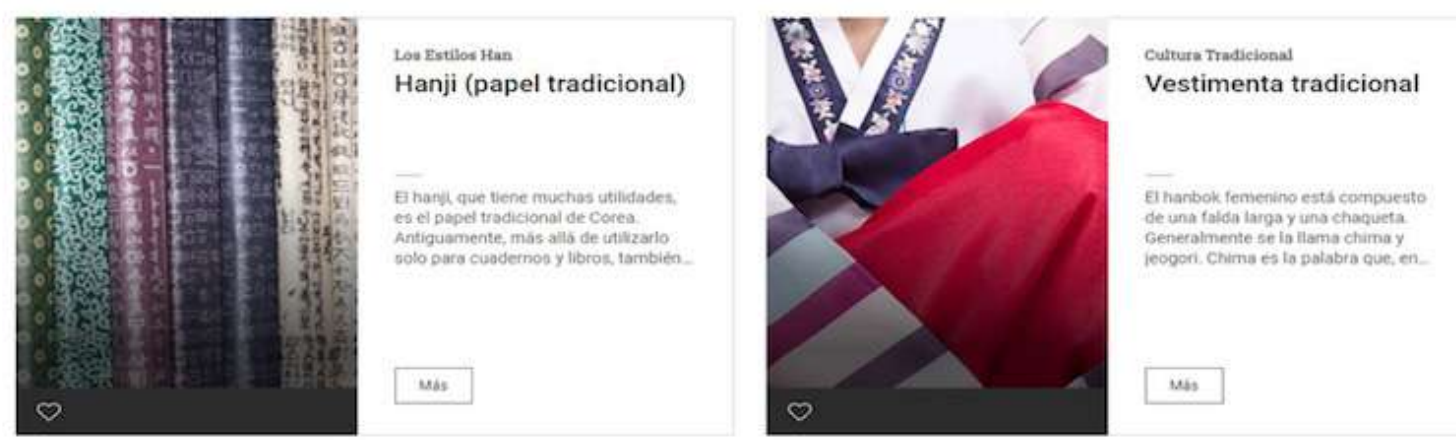

Figura 3. Imagen captada de Vestimenta tradicional de VisitKorea. Recuperado de https://spanish.visitkorea.or.kr/ spa/KOl/6_2_list.kto

pasando por otros datos de interés funcionales y prácticos, como información detallada sobre restaurantes, alojamientos, transportes, recomendaciones del mes en que se viaja, etc. Además, está traducida a once idiomas. ${ }^{9}$

Nuestro corpus de culturemas relativos a la vestimenta tradicional coreana procede de la sección Cultura e idioma, y específicamente de la subsección Cultura tradicional y Vestimenta tradicional. ${ }^{10}$ En cuanto a la vestimenta, a través de textos escritos y fotografías, se presenta y describe el traje típico tradicional coreano, el hanbok, así como las formas de producción y su uso.

El vaciado de los textos dedicados a la vestimenta tradicional ha arrojado un total de 18 culturemas referidos a prendas de hombre, mujer y niños, además de accesorios y adornos complementarios al hanbok. Los culturemas que hemos seleccionado para el presente trabajo se representan en la Tabla 2, acompañados

9 Según información obtenida en una entrevista realizada por vía telefónica a KTO, para la traducción de los textos en esta página web se realizan los siguientes pasos: 1) se redactan los textos en coreano; 2) estos son traducidos por traductores coreanos y 3 ) son revisados por extranjeros nativos de las distintas lenguas.

10 http://spanish.visitkorea.or.kr/spa/KOI/6_2_ view.jsp?cid $=2537475$ de las definiciones procedentes en su mayoría del Diccionario didáctico de coreano-español del Instituto Nacional de la Lengua Coreana (DD$\mathrm{CE})^{11}$, un diccionario bilingüe (coreano-español), o, en caso de que el citado diccionario no lo tuviera registrado, recurrimos al Gran diccionario estándar de coreano (GDEC) ${ }^{12}$ del mismo instituto, pero monolingüe, al que incorporamos una traducción propia fiel a la definición.

\section{Metodología de análisis}

Una vez realizado el vaciado de nuestro corpus, procederemos a analizar los culturemas del ámbito de la vestimenta tradicional de Corea:

11 Es un diccionario didáctico en versión digital y de acceso libre publicado en Corea por el Instituto Nacional de la Lengua Coreana. Robles Ávila y Park (2021) realizaron una investigación sobre los culturemas gastronómicos de Corea y su tratamiento en los diccionarios coreano-español. Emplearon este diccionario y otro convencional, de soporte en papel, para comparar las definiciones en su lemario. Concluyeron que el Diccionario didáctico coreano-español contiene definiciones suficientemente satisfactorias de los culturemas gastronómicos coreanos. Por esta razón, también utilizaremos este recurso para la presente investigación. (véase: https://krdict.korean.go.kr/m/ spa/help?nation=spa).

12 Traducción literal de 표준국어대사전 [traducción propia] (https://stdict.korean.go.kr/main/ main.do). 
Tabla 2. Corpus de culturemas con sus definiciones

\begin{tabular}{|c|c|}
\hline Culturema [transcripción] & Definición \\
\hline 한복 [hanbok] & Traje tradicional de Corea. (DDCE) \\
\hline 고름 [goreum] & $\begin{array}{l}\text { Par de cordones o tiras que cuelgan de cada delantera del abrigo o la blusa que } \\
\text { compone la vestimenta tradicional hanbok, que se atan para cerrar la prenda } \\
\text { de vestir. (DDCE) }\end{array}$ \\
\hline 저고리 [jeogori] & Parte superior de traje tradicional coreano. (DDCE) \\
\hline 바지 [baji] & $\begin{array}{l}\text { Prenda de vestir para la parte inferior del cuerpo, que se ajusta a la cintura y } \\
\text { tiene dos perneras. (DDCE) }\end{array}$ \\
\hline 동정 [dongjeong] & $\begin{array}{l}\text { Tirilla blanca y dura para cuello de la camisola del hanbok, vestido tradicional } \\
\text { coreno. (DDCE) }\end{array}$ \\
\hline 배래 [baerae] & $\begin{array}{l}\text { La línea curva de las mangas de la parte superior del hanbok, que se parece al } \\
\text { abdomen de un pez. (GDEC) [traducción propia] }\end{array}$ \\
\hline 족두리 [jokduri] & $\begin{array}{l}\text { Objeto pequeño y de forma un poco rectangular que las mujeres solían colocar } \\
\text { sobre la cabeza cuando se vestían formalmente. (DDCE) }\end{array}$ \\
\hline 깃 [git] & $\begin{array}{l}\text { Parte superior de ciertas prendas de ropa la cual rodea el cuello y se lleva } \\
\text { doblándola hacia fuera. (DDCE) }\end{array}$ \\
\hline 갓 $[\mathrm{gat}]$ & Sombrero de ala ancha y redonda que utilizaban los hombres adultos. (DDCE) \\
\hline 꽃신 [kkotsin] & Calzado bellamente decorado con dibujos florales o con varios colores. (DDCE) \\
\hline 치마 [chima] & $\begin{array}{l}\text { Prenda de vestir o parte del vestido de mujer que cae desde la cintura sin ceñirse } \\
\text { a las piernas. (DDCE) }\end{array}$ \\
\hline 당의 [dangui] & $\begin{array}{l}\text { Es una vestimenta femenina que se usa por encima de jeogori. (GDEC) [traducción } \\
\text { propia] }\end{array}$ \\
\hline 조끼 [joggi] & Prenda de vestir sin mangas que se pone encima de la camisa. (DDCE) \\
\hline 원삼 [wonsam] & $\begin{array}{l}\text { Wonsam. Prenda del hanbok que generalmente se colocaban las novias o las } \\
\text { mujeres de alto rango en el palacio. (DDCE) }\end{array}$ \\
\hline 마고자 [magoja] & $\begin{array}{l}\text { Magoja, abrigo. Abrigo tradicional coreano sin cuello usado sobre el traje } \\
\text { hanbok, el cual se cierra con botones en lugar de cordones en ambas } \\
\text { delanteras. (DDCE) }\end{array}$ \\
\hline 버선 [beoseon] & $\begin{array}{l}\text { Prenda que se pone en los pies, como calcetines o medias. Está hecha para } \\
\text { tener una forma semejante al pie y se usa generalmente con el traje tradicional } \\
\text { coreano hanbok. (DDCE) }\end{array}$ \\
\hline 금관조복 [geumgwanjobok] & $\begin{array}{l}\text { Es una palabra que se usa para referirse al conjunto de corona dorada y traje } \\
\text { que portaban los funcionarios de alto rango. Es uno de los atuendos más nobles; } \\
\text { se utilizaba para ocasiones especiales. (GDEC) [traducción propia] }\end{array}$ \\
\hline 두루마기 [durumagi] & $\begin{array}{l}\text { Hanbok (vestimenta tradicional coreana) largo que se pone cuando se sale de la } \\
\text { casa. (DDCE) }\end{array}$ \\
\hline
\end{tabular}

el hanbok. En nuestro primer acercamiento al conjunto de culturemas, hemos identificado la presencia de una serie de técnicas ${ }^{13}$ empleadas de manera recurrente en la trasposición

13 El término técnica, de hecho, es una denominación que genera discrepancia respecto a método y estrategia, sin embargo, coincidiendo con Hurtado Albir (2018, p. 257), se aplica a las unidades en el plano microtextual. de términos coreanos al español y que, como hemos mencionado anteriormente, forman parte del listado propuesto por Molina Martínez y Hurtado Albir (2002, pp. 509-511), al que se suman otras técnicas para la ampliación de información de las unidades o segmentos marcados culturalmente de Mayoral Asensio y Muñoz Martín (1997, pp.148-149). No obstante, al trabajar con culturemas relativos a la vestimenta tradicional coreana, aquella 
empleada desde la antigüedad, que se ha ido consolidando, preservando como patrimonio a lo largo de los siglos, pero que en la actualidad tiene un uso restringido a determinadas celebraciones, eventos y circunstancias, se amplía aún más la ya honda brecha cultural entre Corea y los países hispanos, al añadir también la distancia temporal de una indumentaria más propia de otra época.

Esta circunstancia justifica que tengamos que recurrir a la traducción explicativa como técnica eficaz para trasladar una referencia cultural de una lengua de partida que no cuenta con un equivalente en la lengua meta (Campos Martín, 2011, p. 42). Así pues, una profunda reflexión y observación de nuestros culturemas nos ha permitido emplear las propuestas referidas, aunque dándole un papel preferente a la traducción explicativa o parafrástica ${ }^{14}$. La lista siguiente organiza nuestra tipología de técnicas para analizar estos culturemas y las complementa con la definición correspondiente.

\section{Préstamo: ya sea transcripción fonética o préstamo puro.}

2. Particularización: reemplazo del referente de la lengua de origen por otro más concreto de la lengua meta, generalmente un hipónimo.

3. Generalización: reemplazo del referente de la lengua de origen por otro más general de la lengua meta, generalmente un hiperónimo.

14 Por ejemplo, en el caso de la propuesta de Molina Martínez y Hurtado Albir (2002), las técnicas similares o equivalentes a la traducción explicativa son la amplificación y la descripción. La diferencia entre la amplificación y la descripción es la presencia del préstamo o el propio nombre del referente. No obstante, la amplificación no necesariamente requiere una traducción explicativa. Por su parte, la descripción es la técnica que se concreta generalmente mediante una paráfrasis.
4. Equivalente acuñado: empleo de un término en la lengua meta reconocido como equivalente.

5. Identificación del usuario: se ofrece información sobre el portador del atuendo: sexo, clase social o edad.

6. Descripción de aspecto: el término se representa en la lengua meta mediante una descripción de su apariencia, su forma peculiar, sus colores, etc.

7. Descripción de información histórica: el término se traslada a la lengua meta a través de una descripción de hechos históricos relevantes asociados al referente y directamente relacionados con él.

8. Descripción de complementos: la traslación consiste en la explicación de los complementos o prendas que conforman el referente.

9. Descripción de producción: la traslación consiste en la explicación del procedimiento de producción y los materiales utilizados.

10.Descripción de uso: La traslación consiste en la explicación de la forma de vestir de ese referente cultural, su colocación o las ocasiones cuando se emplea.

Para proceder con el análisis, en la Tabla 3 hemos elaborado la ficha que aplicaremos en el estudio de cada culturema.

Como se aprecia, la ficha está dividida en tres partes: en la sección A se presenta el referente material del culturema mediante fotografías, lo que facilitará su identificación y comprensión. ${ }^{15}$ En la sección $B$ se ofrece información general del culturema en la lengua de origen,

15 Las imágenes ilustrativas de los culturemas se han tomado de dos fuentes: la web Park Sul Nyeo Hanbok (n. d.) y la Encyclopedia of Korean Culture of Basic Necessities. CLOTHING I (2017a) y II (2017b). Para el uso legítimo de las imágenes, hemos pedido la correspondiente autorización a la autora (anotada en la 
Tabla 3. Ficha de análisis

A. Imagen referencial del culturema
B. Información general del culturema en la lengua de origen
1. Culturema
2. Definición
C. Análisis del culturema en la lengua meta
3. Contexto
4. Segmentación
5. Técnicas utilizadas

mientras que en la $\mathrm{C}$ se analiza el culturema en la lengua meta.

En la la sección $B$, se presenta información general, como el culturema (punto 1), que es la referencia de la lengua de origen, y su definición (punto 2) que, como anunciamos anteriormente, se obtiene del Diccionario didáctico coreano-español del Instituto Nacional de la Lengua Coreana (DDCE) o, en su defecto, del Gran diccionario estándar de coreano (GDEC). En la sección $\mathrm{C}$, correspondiente al análisis, recogemos el contexto (punto 3) que rodea al culturema ya trasladado a la lengua meta - frase donde se incluye un pequeño fragmento textual, etc.- - Se da el caso de que en nuestro corpus aparecen culturemas en distintos contextos para los que se ofrecen traslaciones diferentes; todas ellas aparecen recogidas en el análisis. A continuación, en segmentación (punto 4), fragmentaremos, siempre que sea posible, la información procedente de la traslación del culturema. Esta fragmentación se divide en segmentos según las técnicas empleadas en el trasvase, las cuales se indicarán con un número entre corchetes. Por último, en técnicas

bibliografía) y al National Folk Museum of Korea, entidad que publicó esta enciclopedia. utilizadas (punto 5), enumeraremos las técnicas que se emplean en cada segmento de la traslación.

\section{Análisis}

Esta sección presenta el análisis de los 18 culturemas seleccionados pertenecientes al campo semántico de la vestimenta tradicional coreana. Para cada culturema se presenta la imagen que representa la parte de la indumentaria y en la tabla del mismo número, la ficha de análisis del término, incluyendo las técnicas de traducción empleadas, como se explicó en la sección 4. Así, los términos seleccionados son hanbok (Figura 4 y Tabla 4), goreum (Figura 5 y Tabla 5), jeogori (Figura 6 y Tabla 6), baji (Figura 7 y Tabla 7), dongjeong (Figura 8 y Tabla 8), baerae (Figura 9 y Tabla 9), jokduri (Figura 10 y Tabla 10), git (Figura 11 y Tabla 11), gat (Figura 12 y Tabla 12), kkotsin (Figura 13 y Tabla 13), chima (Figura 14 y Tabla 14), dangui (Figura 15 y Tabla 15), joggi (Figura 16 y Tabla 16), wonsam (Figura 17 y Tabla 17), magoja (Figura 18 y Tabla 18), beoseon (Figura 19 y Tabla 19), geumgwanjobok (Figura 20 y Tabla 20), durumagi (Figura 21 y Tabla 21). 


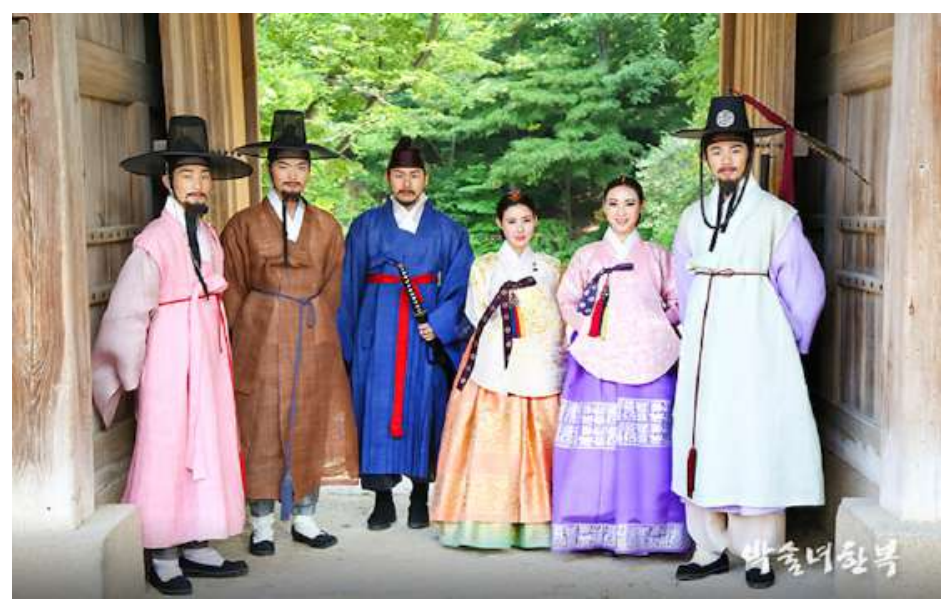

Figura 4. Hanbok. Imagen extraída de Park Sul Nyeo Hanbok (n. d.). Recuperado de http://www. hanbokhouse.co.kr/portfolio page/2019-창덕궁-패션쇼-9/

Tabla 4. Análisis: hanbok

\begin{tabular}{|c|c|}
\hline Culturema 1 & Hanbok [한복]* \\
\hline Definición & Traje tradicional de Corea. (DDCE). \\
\hline Contexto 1 & $\begin{array}{l}\text { El hanbok femenino está compuesto de una falda larga y una chaqueta. Generalmente se } \\
\text { la llama chima y jeogori. }\end{array}$ \\
\hline Segmentación & $\begin{array}{l}\text { El hanbok [1] femenino [2] está compuesto de una falda [3]/[4] larga [5] y una chaqueta [3]/ } \\
\text { [4]. Generalmente se la llama chima [1] y jeogori [1]. }\end{array}$ \\
\hline Técnicas utilizadas & [1] Préstamo + [2] Usuario + [3] Complementos + [4] Generalización + [5] Aspecto \\
\hline Contexto 2 & $\begin{array}{l}\text { El hanbok del hombre consiste en una chaqueta corta y pantalones, llamados baji, que } \\
\text { son amplios y van atados a los tobillos. Ambas prendas pueden ser acompañadas por un } \\
\text { sobretodo largo, de un corte similar, llamado durumagi. }\end{array}$ \\
\hline Segmentación & $\begin{array}{l}\text { El hanbok [1] del hombre [2] consiste en una chaqueta [3]/[4] corta [5] y pantalones [3]/ } \\
\text { [6], llamados baji [1], que son amplios [5] y van atados a los tobillos [7]. Ambas prendas } \\
\text { pueden ser acompañadas [7] por un sobretodo [3]/[8] largo [5], de un corte similar [5], } \\
\text { llamado durumagi[1]. }\end{array}$ \\
\hline Técnicas utilizadas & $\begin{array}{l}\text { [1] Préstamo + [2] Usuario + [3] Complementos + [4] Generalización + [5] Aspecto + [6] } \\
\text { Equivalente acuñado + [7] Uso + [8] Particularización }\end{array}$ \\
\hline Contexto 3 & $\begin{array}{l}\text { El hanbok que se usa hoy en día fue diseñado después de la dinastía Joseon (1392-1910) con } \\
\text { orientación confuciana. Los yangban, una clase aristocrática hereditaria, basada más en } \\
\text { la educación y posiciones oficiales que en la riqueza, vestían hanbok de colores claros, de } \\
\text { diseños simples, de seda en invierno; y de hilo tejido, u otro material liviano durante el verano. }\end{array}$ \\
\hline Segmentación & $\begin{array}{l}\text { El hanbok [1] que se usa hoy en día fue diseñado después de la dinastía Joseon (1392-1910) } \\
\text { con orientación confuciana [2]. Los yangban [1], una clase aristocrática hereditaria[3], } \\
\text { basada más en la educación y posiciones oficiales que en la riqueza [2], vestían hanbok } \\
\text { [1] de colores claros [4], de diseños simples [4], de seda [5] en invierno [6]; y de hilo tejido, U } \\
\text { otro material liviano[5] durante el verano[6]. }\end{array}$ \\
\hline Técnicas utilizadas & [1] Préstamo + [2] Historia + [3] Usuario + [4] Aspecto + [5] Producción + [6] Uso \\
\hline Contexto 4 & $\begin{array}{l}\text { La clase baja, por otro lado, fue restringida por ley a utilizar hanbok de cáñamo almidonado } \\
\text { y de algodón, y solo podían vestir de color blanco, rosa viejo, verde claro, gris o negro. }\end{array}$ \\
\hline Segmentación & $\begin{array}{l}\text { La clase baja [1], por otro lado, fue restringida por ley [2] a utilizar hanbok [3] de cáñamo } \\
\text { almidonado y de algodón [4], y solo podían vestir de color blanco, } \underline{\text { rosa viejo }} \text {, verde claro, } \\
\text { gris o negro [5]. }\end{array}$ \\
\hline Técnicas utilizadas & [1] Usuario + [2] Historia + [3 ]Préstamo + [4] Producción + [5] Aspecto \\
\hline
\end{tabular}

* El culturema hanbok, está formado por han-, el adjetivo 'coreano' y -bok, un sustantivo que significa 'vestimenta'. 


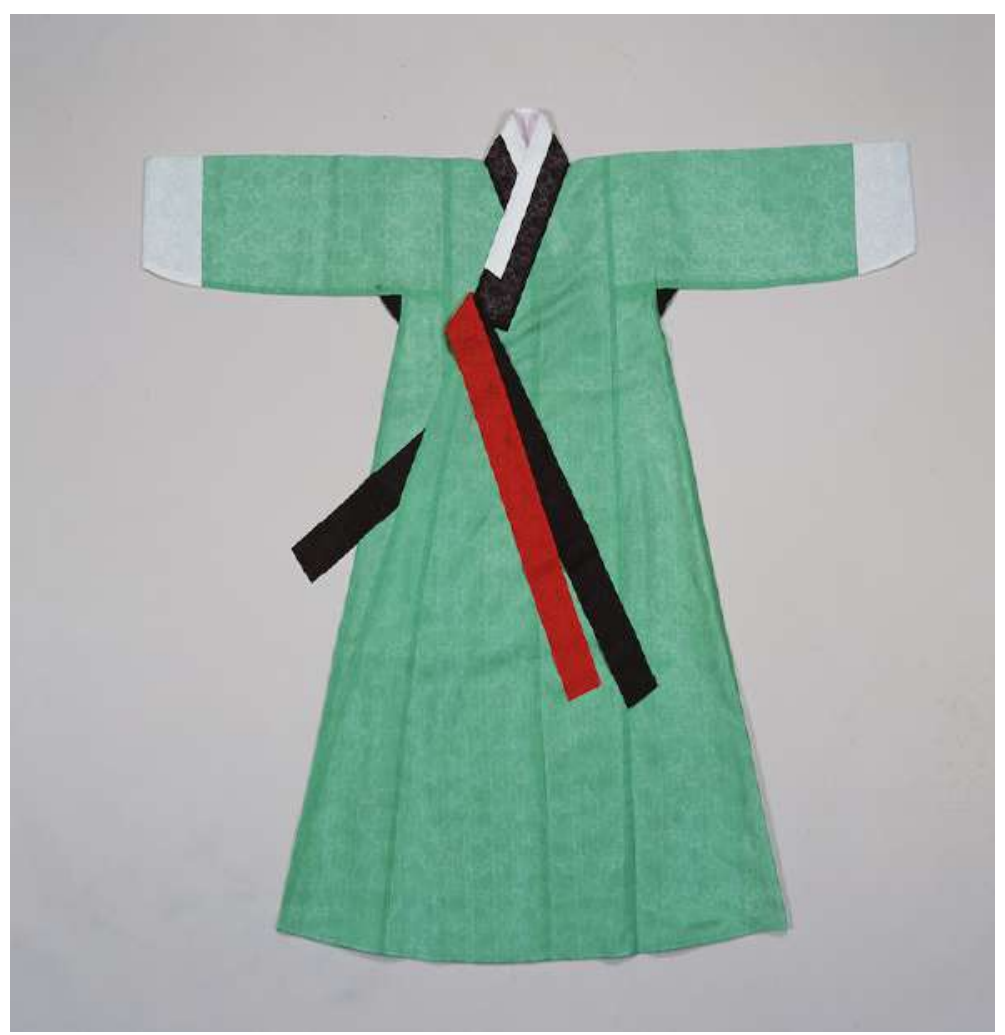

Figura 5. Goreum. Imagen extraída de Encyclopedia of Korean Culture of Basic Necessities. Clothing ॥ (National Folk Museum of Korea, 2017b, p. 583).

Tabla 5. Análisis: goreum

\begin{tabular}{|c|c|}
\hline Culturema 2 & Otgoreum o goreum (고름)* \\
\hline Definición & $\begin{array}{l}\text { Goreum, cordones, tiras. Par de cordones o tiras que cuelgan de cada delantera del abrigo o } \\
\text { la blusa que compone la vestimenta tradicional hanbok, que se atan para cerrar la prenda de } \\
\text { vestir. (DDCE). }\end{array}$ \\
\hline Contexto 1 & $\begin{array}{l}\text { Otgoreum (lazo de tela). El otgoreum es una pieza de decoración para el hanbok de la mujer, } \\
\text { que se desprende verticalmente desde el jeogori (la chaqueta). }\end{array}$ \\
\hline Segmentación & $\begin{array}{l}\text { Otgoreum [1] (lazo [2] de tela [3]). El otgoreum [1] es una pieza de decoración [2] para } \\
\text { el hanbok [1] de la mujer [4], que se desprende verticalmente [5] desde el jeogori [1]/[6] } \\
\text { chaqueta [2]). }\end{array}$ \\
\hline $\begin{array}{l}\text { Técnicas } \\
\text { utilizadas }\end{array}$ & $\begin{array}{l}\text { [1] Préstamo + [2] Generalización + [3] Producción + [4] Usuario + [5] Aspecto + [6] } \\
\text { Complementos }\end{array}$ \\
\hline
\end{tabular}

* El otgoreum o goreum, empleado tanto por mujeres como por hombres, es una palabra que hace referencia a una tira de tela que se coloca en la parte de arriba del hanbok y se usa para cerrar las solapas. Ot- significa 'ropa' y -goreum hace referencia a esta tira larga con que se hace el lazo. El goreum no necesariamente implica la lazada, sino que alude a estas tiras que se desprenden de la parte de arriba del hanbok, concretamente del jeogori (chaqueta). Otra característica de este complemento es que no cuenta con dos lazadas sino con una.

** Puede ocurrir que en la traslación de un culturema se use otro, enunciado como préstamo, y, a la vez, como parte de la explicación del primero. Es lo que sucede en este caso, donde para definir el complemento decorativo otgoreum se emplea jeogori (chaqueta), referido al lugar donde este se ubica. 


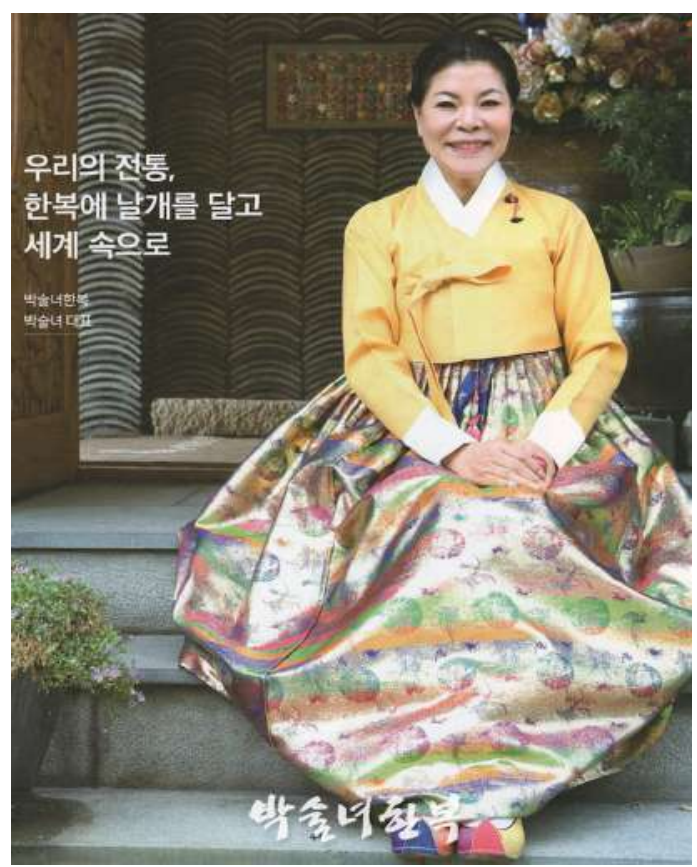

Figura 6. Jeogori. Imagen extraída de Park Sul Nyeo Hanbok (n. d.). Recuperado de http://www. hanbokhouse.co.kr/portfolio_ page/ 11 월-기업은행-사보

Tabla 6. Análisis: jeogori

\begin{tabular}{|c|c|}
\hline Culturema 3 & Jeogori [저고리]* \\
\hline Definición & Parte superior de traje tradicional coreano. (DDCE). \\
\hline Contexto 1 & Chima es la palabra que, en coreano, significa falda y jeogori, chaqueta. \\
\hline Segmentación & Chima es la palabra que, en coreano, significa falda y jeogori [1], chaqueta [2]. \\
\hline Técnicas utilizadas & [1] Préstamo + [2] Generalización \\
\hline Contexto 2 & La mayoría de los jeogori tienen dos lazos, para atar las dos partes, en forma de otgoreum. \\
\hline Segmentación & $\begin{array}{l}\text { La mayoría de los jeogori [1] tienen dos lazos [2], para atar las dos partes [3], en forma } \\
\text { de otgoreum [1]/[2]. }\end{array}$ \\
\hline Técnicas utilizadas & [1] Préstamo + [2] Complementos + [3] Uso \\
\hline Contexto 3 & $\begin{array}{l}\text { El jeogori es la parte de arriba del hanbok. El jeogori del hombre es más largo y simple, } \\
\text { mientras que el jeogori de la mujer es más corto y tiene curvas y delicadas decoraciones. }\end{array}$ \\
\hline Segmentación & $\begin{array}{l}\text { El jeogori [1] es la parte de arriba [2] del hanbok [1]. El jeogori [1] del hombre [3] es más } \\
\text { largo [4] y simple [4], mientras que el jeogori [1] de la mujer [3] es más corto [4] y tiene } \\
\text { curvas [4] y delicadas decoraciones [5]. }\end{array}$ \\
\hline Técnicas utilizadas & [1] Préstamo + [2] Uso + [3] Usuario + [4] Aspecto + [5] Generalización \\
\hline Contexto 4 & $\begin{array}{l}\text { El hanbok de los niños se compone generalmente, de jeogori (chaqueta), chima (falda) } \\
\text { o baji (pantalones), rayado con varios colores. }\end{array}$ \\
\hline Segmentación & $\begin{array}{l}\text { El hanbok de los niños se compone generalmente, de jeogori [1] (chaqueta) } \\
\text { [2], chima (falda) o baji (pantalones), rayado con varios colores. }\end{array}$ \\
\hline Técnicas utilizadas & [1] Préstamo + [2] Generalización \\
\hline Contexto 5 & La novia viste una chima verde (falda), un jeogori amarillo (chaqueta corta)... \\
\hline Segmentación & $\begin{array}{l}\text { La novia viste una chima verde (falda), un jeogori [1] amarillo [2] } \\
\text { (chaqueta [3] corta [2])... }\end{array}$ \\
\hline Técnicas utilizadas & [1] Préstamo + [2] Aspecto + [3] Generalización \\
\hline
\end{tabular}

* El jeogori es la parte de arriba del hanbok. En los contextos 1, 3, 4 y 5 vemos que se ha utilizado la técnica de generalización mediante la palabra chaqueta. En el contexto 3, también se ha empleado la generalización delicadas decoraciones-; un hiperónimo que ofrece una información imprecisa e inespecífica. 


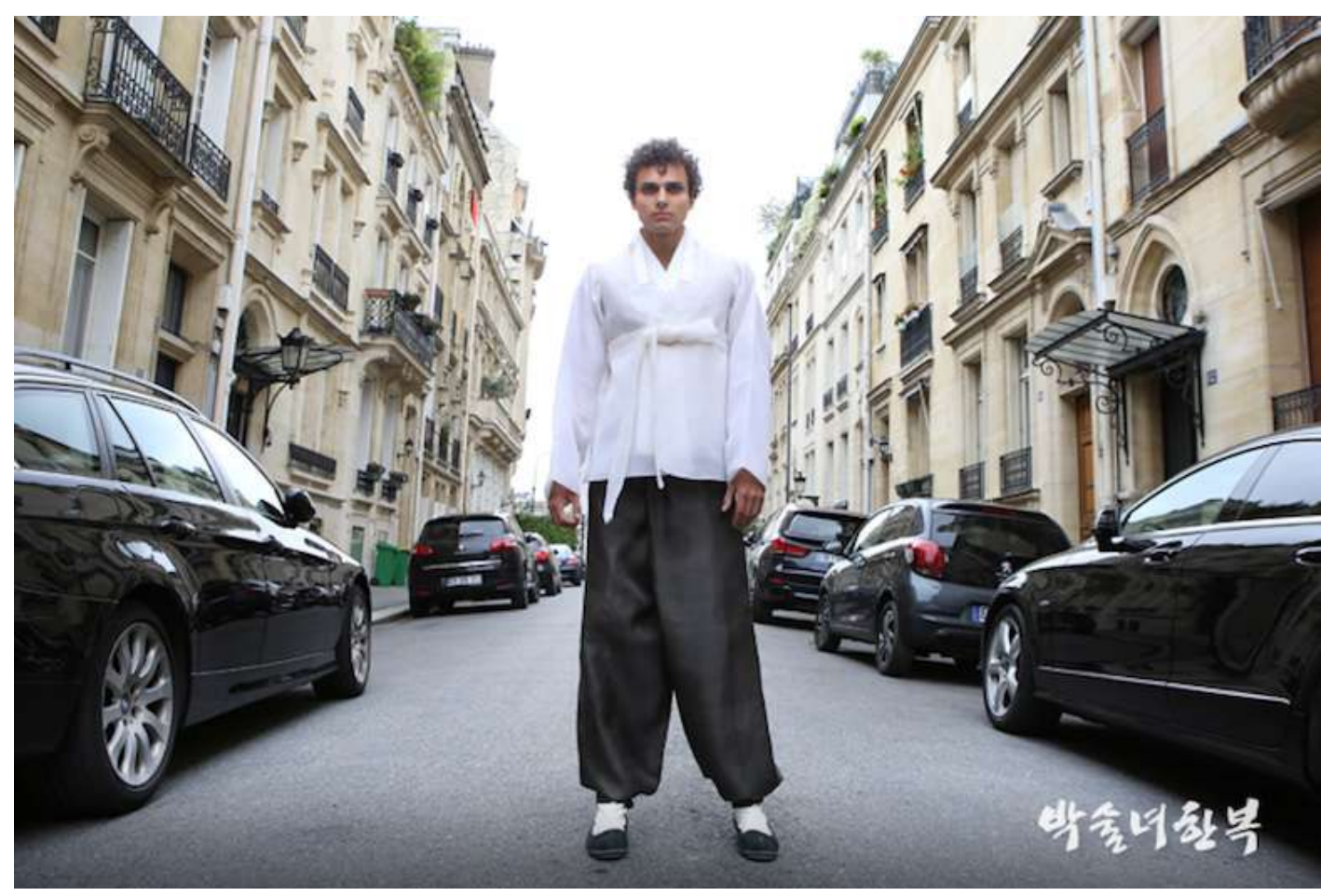

Figura 7. Baji. Imagen extraída de Park Sul Nyeo Hanbok (n. d.). Recuperado de http://www.hanbokhouse.co.kr/ portfolio_page/프랑스-화보-32/

Tabla 7. Análisis: baji

\begin{tabular}{|c|c|}
\hline Culturema 4 & Baji [바지]* \\
\hline Definición & $\begin{array}{l}\text { Pantalón, calzón. Prenda de vestir para la parte inferior del cuerpo que se ajusta a la } \\
\text { cintura y tiene dos perneras. (DDCE). }\end{array}$ \\
\hline Contexto 1 & $\begin{array}{l}\text { Es la parte inferior del hanbok de hombre. Se puede comparar con un pantalón, pero no } \\
\text { es ajustado. Este pantalón fue diseñado lo suficientemente ancho para la comodidad al } \\
\text { sentarse en el piso. }\end{array}$ \\
\hline Segmentación & $\begin{array}{l}\text { Es la parte inferior [1] del hanbok [2] de hombre [3]. Se puede comparar con un pantalón } \\
\text { [4], pero no es ajustado [5]. Este pantalón [4] fue diseñado lo suficientemente ancho [5] } \\
\text { para la comodidad al sentarse en el piso [1]. }\end{array}$ \\
\hline Técnicas utilizadas & [1] Uso + [2] Préstamo + [3] Usuario + [4] Equivalente acuñado + [5] Aspecto \\
\hline Contexto 2 & $\begin{array}{l}\text { El hanbok de los niños se compone generalmente, de jeogori (chaqueta), chima (falda) } \\
\text { o baji (pantalones), rayado con varios colores. }\end{array}$ \\
\hline Segmentación & $\begin{array}{l}\text { El hanbok de los niños se compone generalmente, de jeogori (chaqueta), chima (falda) } \\
\text { o baji [1] (pantalones) [2], rayado con varios colores. }\end{array}$ \\
\hline Técnicas utilizadas & [1] Préstamo + [2] Equivalente acuñado \\
\hline Contexto 3 & $\begin{array}{l}\text { El novio viste el baji (pantalones), joggi (chaleco), el magoja (chaqueta) y } \\
\text { el durumagi (sobretodo). }\end{array}$ \\
\hline Segmentación & $\begin{array}{l}\text { El novio [1] viste el baji [2] (pantalones [3]), joggi (chaleco), el magoja (chaqueta) y } \\
\text { el durumagi (sobretodo). }\end{array}$ \\
\hline Técnicas utilizadas & [1] Usuario + [2] Préstamo + [3] Equivalente acuñado \\
\hline
\end{tabular}

* Baji, de hecho, es una palabra común, que significa 'pantalones.' Históricamente en la tradición coreana solamente los hombres utilizaban este atuendo. Sin embargo, lo hemos incluido dado que en este texto la citada referencia designa a los pantalones tradicionales de Corea 


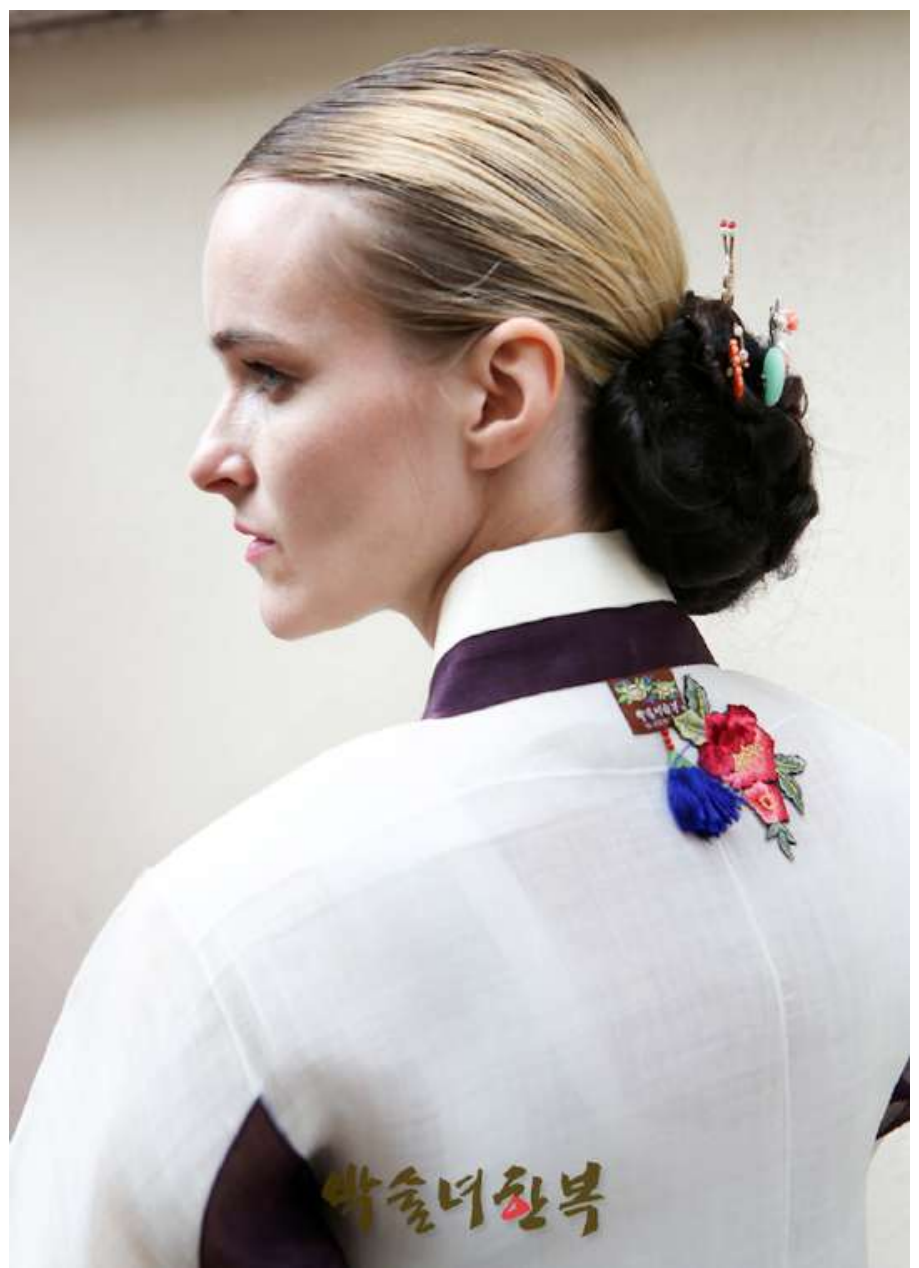

Figura 8. Dongjeong. Imagen extraída de Park Sul Nyeo Hanbok (n. d.). Recuperado de http://www. hanbokhouse.co.kr/portfolio_page/프랑스-화보-37/

Tabla 8. Análisis: dongjeong

\begin{tabular}{|c|c|}
\hline Culturema 5 & Dongjeong [동정]* \\
\hline Definición & $\begin{array}{l}\text { Dongjeong. Tirilla blanca y dura para cuello de la camisola del hanbok, vestido tradicional } \\
\text { coreano. (DDCE). }\end{array}$ \\
\hline Contexto 1 & $\begin{array}{l}\text { Los extremos del git son generalmente rectangulares y se coloca sobre él un collar blanco, } \\
\text { desmontable, llamado dongjeong. }\end{array}$ \\
\hline Segmentación & $\begin{array}{l}\text { Los extremos del git son generalmente rectangulares y se coloca sobre él un collar [1] } \\
\text { blanco [2], desmontable [3], llamado dongjeong [4]. }\end{array}$ \\
\hline Técnicas utilizadas & [1] Particularización + [2] Aspecto + [3] Producción + [4] Préstamo \\
\hline Contexto 2 & $\begin{array}{l}\text { Dongjeong. El dongjeong es la parte blanca junto al cuello y el borde del escote, que } \\
\text { contrasta y armoniza con la línea general del cuello. }\end{array}$ \\
\hline Segmentación & $\begin{array}{l}\text { Dongjeong [1]. El dongjeong [1] es la parte blanca [2] junto al cuello y el borde del escote } \\
\text { [3], que contrasta y armoniza con la línea general del cuello [2]. }\end{array}$ \\
\hline Técnicas utilizadas & [1] Préstamo + [2] Aspecto + [3] Uso \\
\hline
\end{tabular}

* El donjeong es una tela que se ubica en la parte del cuello. Actualmente su uso es poco frecuente en el lenguaje común, y se considera un arcaísmo propio del léxico de especialidad de los profesionales de la moda. 


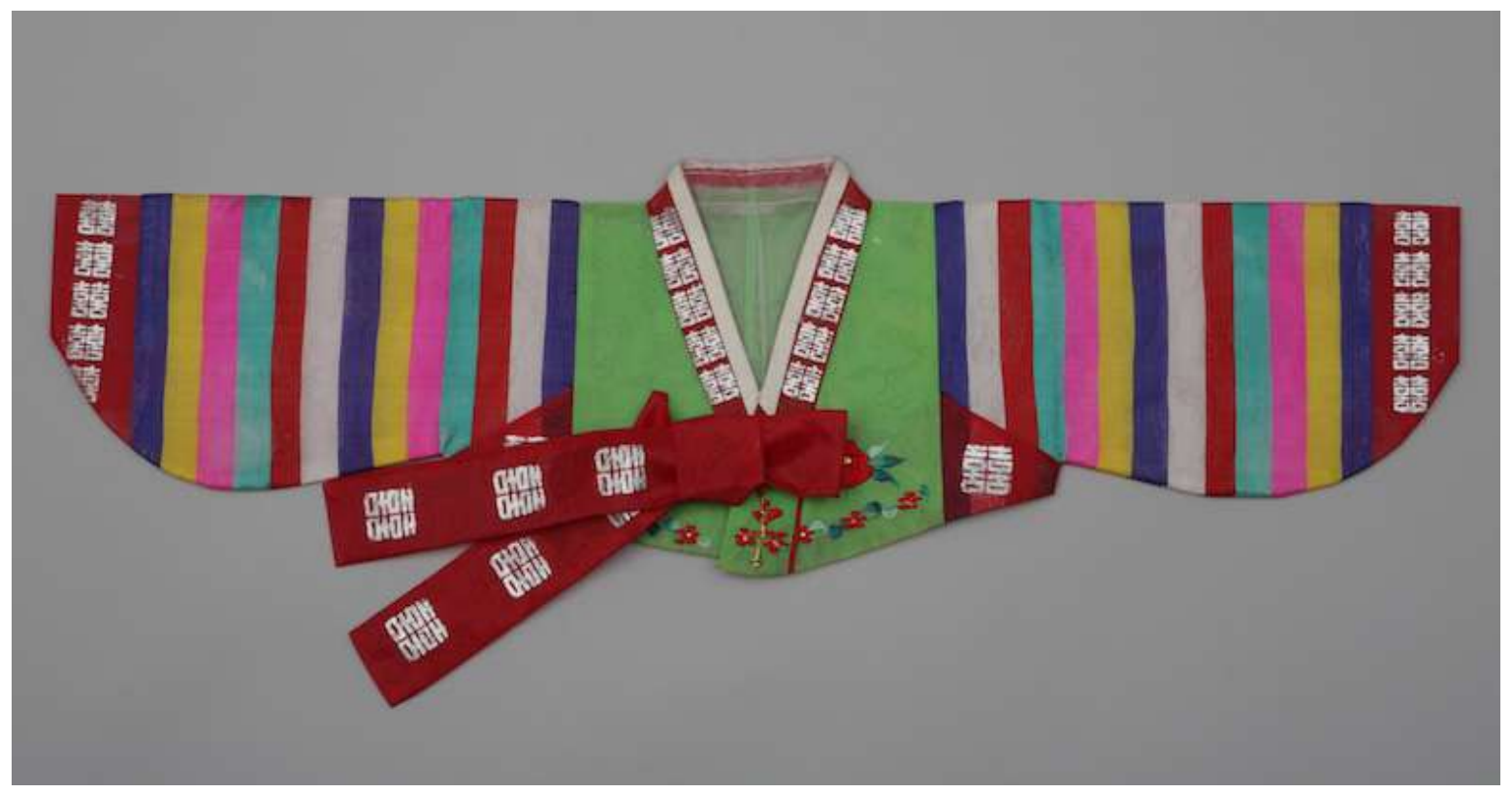

Figura 9. Baerae. Imagen extraída de Encyclopedia of Korean Culture of Basic Necessities. Clothing "I (National Folk Museum of Korea, 2017b, p. 457).

Tabla 9. Análisis: baerae

\begin{tabular}{|c|c|}
\hline Culturema 6 & Baerae [배래]* \\
\hline Definición & $\begin{array}{l}\text { La línea curva de las mangas de la parte superior del hanbok, que se parece al abdomen } \\
\text { de un pez. (GDEC) [Traducción propia]. }\end{array}$ \\
\hline Contexto 1 & Las otras dos cosas son: la curva de las mangas, baerae;... \\
\hline Segmentación & Las otras dos cosas son: la curva [1] de las mangas [2], baerae [3];... \\
\hline Técnicas utilizadas & [1] Aspecto + [2] Complementos + [3] Préstamo \\
\hline Contexto 2 & Baerae (manga del jeogori). \\
\hline Segmentación & Baerae [1] (manga [2] del jeogori [1]/[3]). \\
\hline Técnicas utilizadas & [1] Préstamo + [2] Generalización + [3] Complementos \\
\hline Contexto 3 & $\begin{array}{l}\text { El baerae es la línea inferior de la manga del jeogori (la chaqueta tradicional) o del } \\
\text { magoja. Está decorado con líneas circulares, con curvas naturales, similar a la línea de los } \\
\text { aleros de las casas tradicionales coreanas. }\end{array}$ \\
\hline Segmentación & $\begin{array}{l}\text { El baerae [1] es la línea inferior [2] de la manga [3] del jeogori [1]/[3] (la chaqueta [4] } \\
\text { tradicional) o del magoja [1]/[3]. Está decorado [5] con líneas circulares [2], con curvas } \\
\text { naturales, similar a la línea de los aleros de las casas tradicionales coreanas [2]. }\end{array}$ \\
\hline Técnicas utilizadas & [1] Préstamo + [2] Aspecto + [3] Complementos + [4] Generalización + [5] Producción \\
\hline
\end{tabular}

* En el contexto 1, con 'mangas' se refiere a la parte donde se ubica esta línea. Sin embargo, en el 2, la referencia baerae se ha generalizado como 'mangas'. Verdaderamente el baerae no alude a las mangas, sino a la línea inferior de estas. 


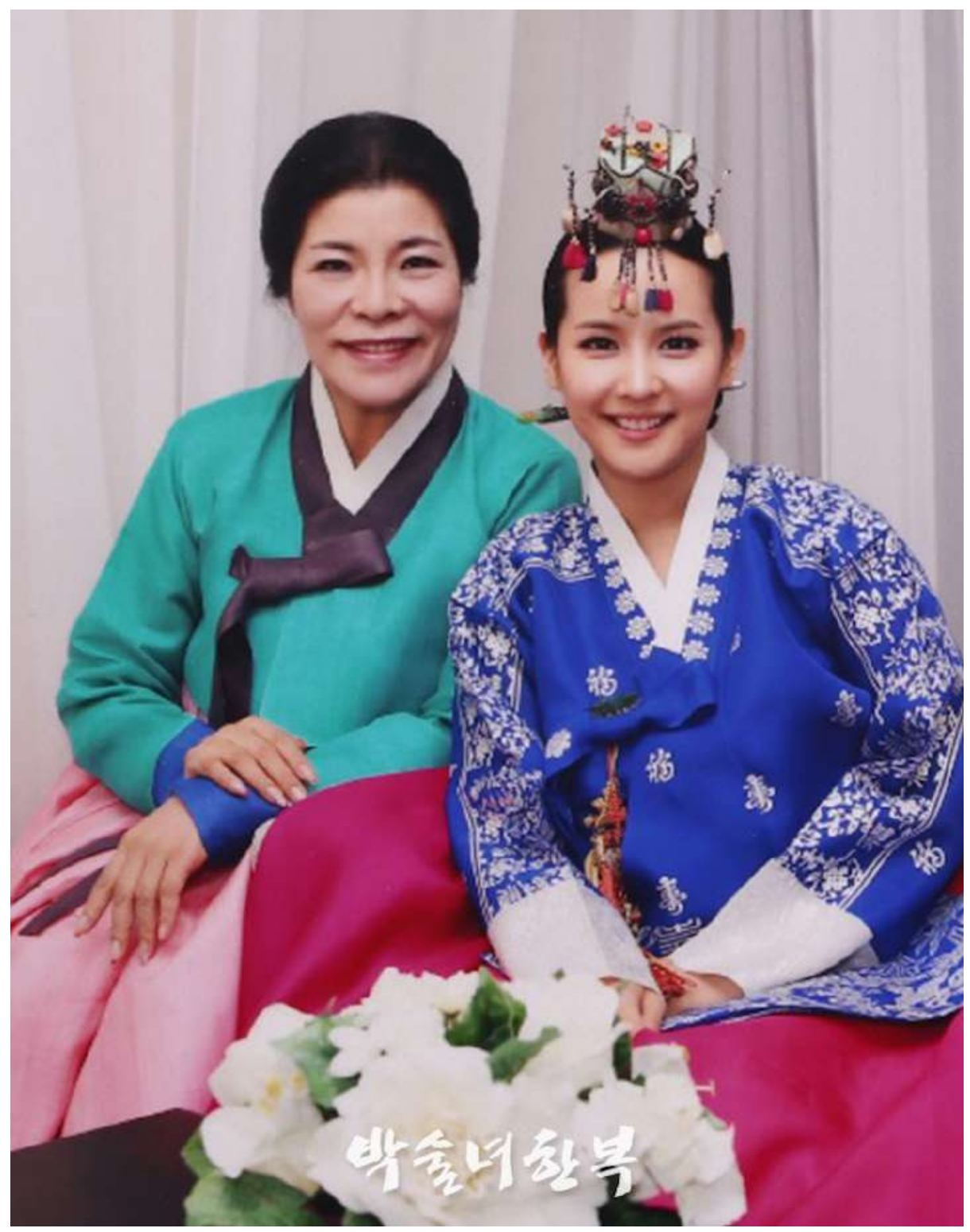

Figura 10. Jokduri. Imagen extraída de Park Sul Nyeo Hanbok (n. d.). Recuperado de http://www.hanbokhouse. co.kr/portfolio_page/2007년-웨딩-패션쇼-1/

Tabla 10. Análisis: jokduri

\begin{tabular}{|c|c|}
\hline Culturema 7 & Jokduri [족두리]* \\
\hline Definición & $\begin{array}{l}\text { Jokduri. Objeto pequeño y de forma un poco rectangular que las mujeres solían colocar } \\
\text { sobre la cabeza cuando se vestían formalmente. (DDCE). }\end{array}$ \\
\hline Contexto 1 & El peinado de la novia está decorado con el jokduri (un adorno especial para el peinado). \\
\hline Segmentación & $\begin{array}{l}\text { El peinado de la novia [1] está decorado [2] con el jokduri [3] (un adorno especial [4] para } \\
\text { el peinado [2]). }\end{array}$ \\
\hline Técnicas utilizadas & [1] Usuario + [2] Uso + [3] Préstamo + [4] Generalización \\
\hline
\end{tabular}

* Este complemento es un adorno que se colocaba en la cabeza de la novia en la boda. Históricamente tiene su origen en Mongolia, país que conquistó Corea en el siglo XIII.

Nuevas perspectivas de investigación en la traducción especializada en lenguas románicas: aspectos comparativos, léxicos, fraseológicos, discursivos y didácticos 
Traducción de culturemas en textos turísticos: tratamiento en español de las voces que designan la vestimenta tradicional coreana

327

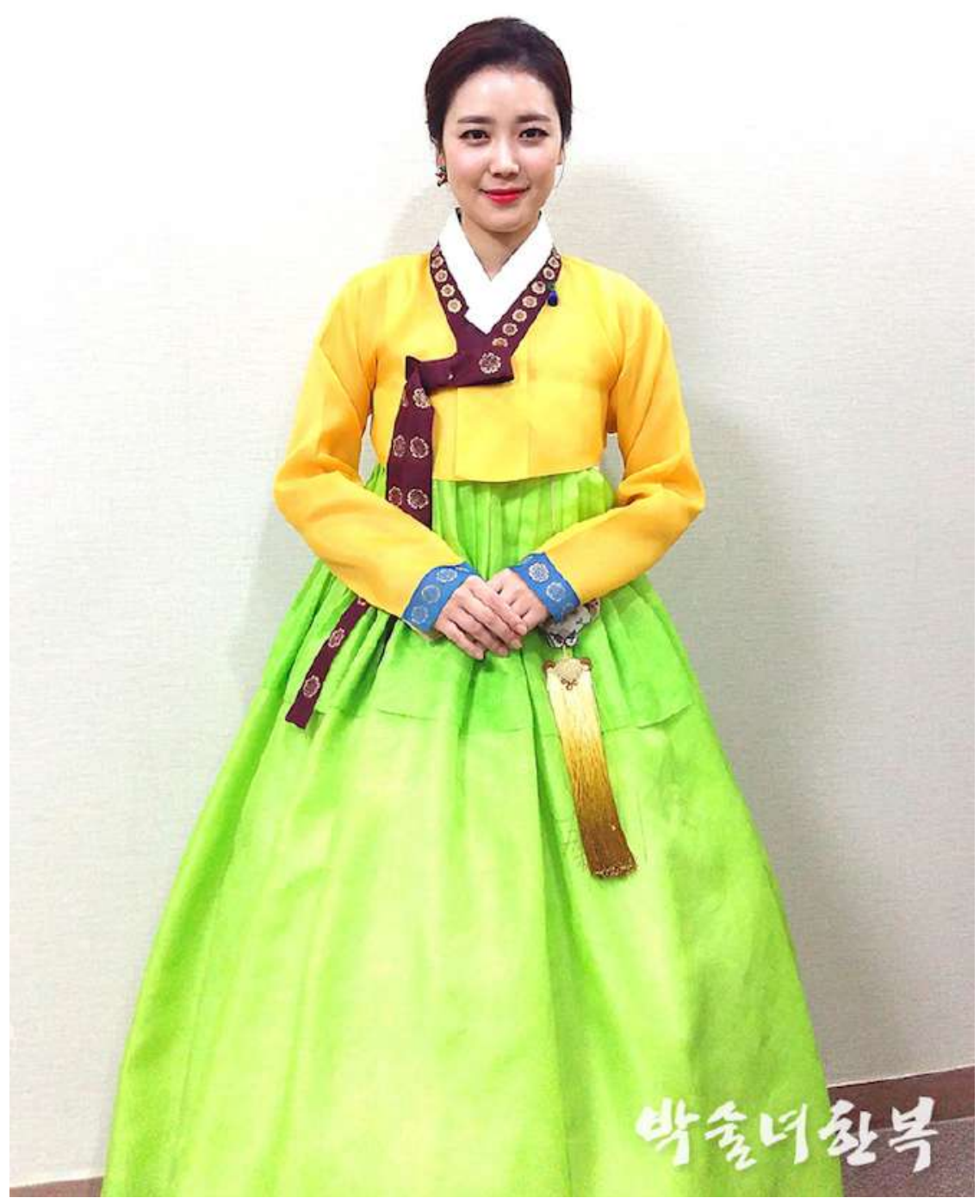

Figura 11. Git. Imagen extraída de Park Sul Nyeo Hanbok (n. d.). Recuperado de http://www.hanbokhouse.co.kr/ portfolio_page/국악한마당-사회자-가애란-아나운서-5/

Tabla 11. Análisis: git

\begin{tabular}{|c|c|}
\hline Culturema 8 & Git [깃] \\
\hline Definición & $\begin{array}{l}\text { Parte superior de ciertas prendas de ropa la cual rodea el cuello y se lleva doblándola } \\
\text { hacia fuera. (DDCE). }\end{array}$ \\
\hline Contexto 1 & $\begin{array}{l}\text {...y la forma del git, una banda de tela que adorna el cuello y la parte delantera del jeogori. } \\
\text { Los extremos del git son generalmente rectangulares y se coloca sobre él un collar blanco, } \\
\text { desmontable, llamado dongjeong. }\end{array}$ \\
\hline Segmentación & $\begin{array}{l}\text {...y la forma del git [1], una banda [2] de tela [3] que adorna el cuello y la parte delantera } \\
\text { [4] del jeogori [1]/[5]. Los extremos del git [1] son generalmente rectangulares [6] y se } \\
\text { coloca sobre él [4] un collar [7] blanco [6], desmontable [3], llamado dongieong [1]/[5]. }\end{array}$ \\
\hline Técnic & $\begin{array}{l}\text { [1] Préstamo + [2] Generalización + [3] Producción + [4] Uso + [5] Complementos + [6] } \\
\text { Aspecto + [7] Particularización }\end{array}$ \\
\hline
\end{tabular}




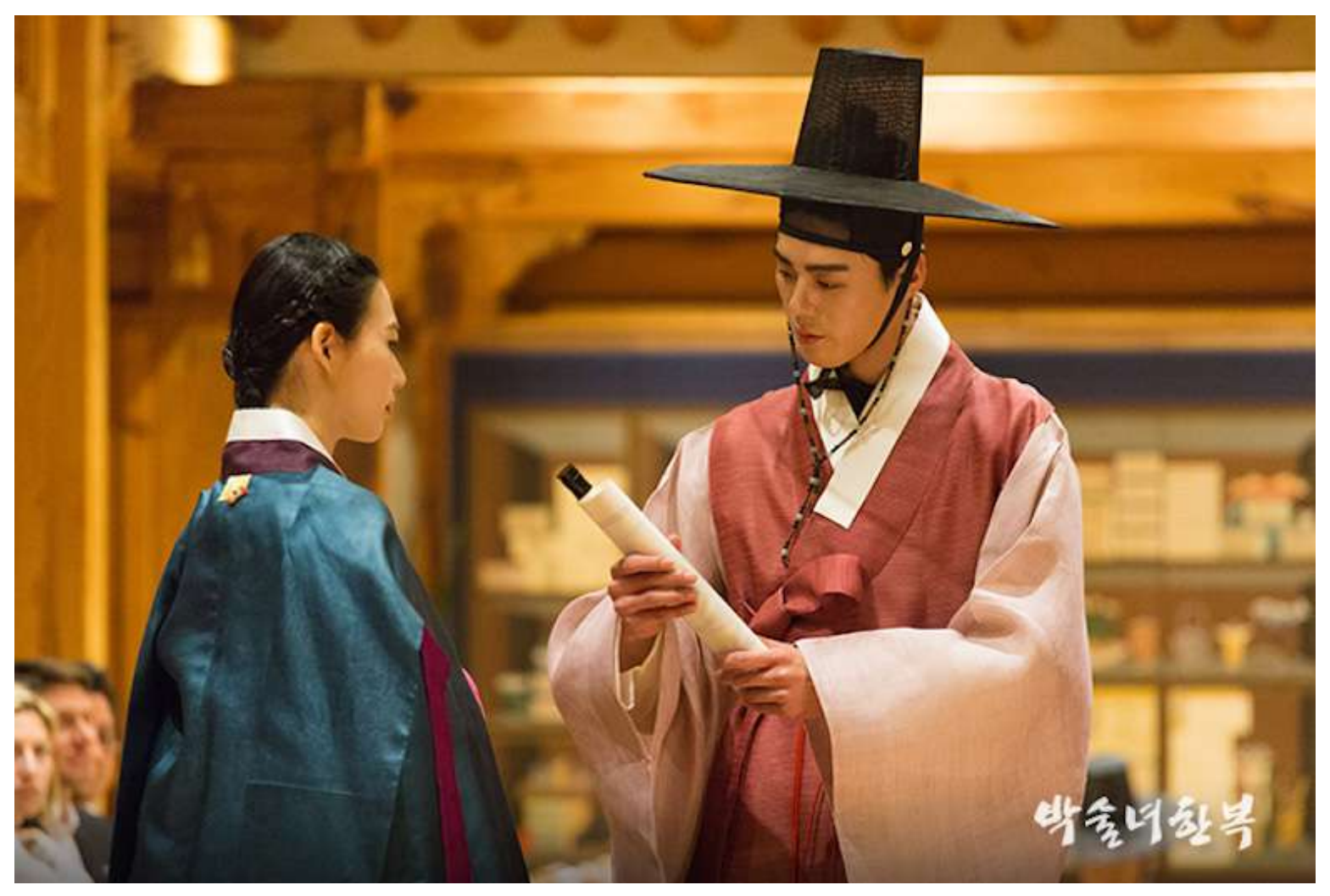

Figura 12. Gat. Imagen extraída de Park Sul Nyeo Hanbok (n. d.). Recuperado de http://www.hanbokhouse.co.kr/ portfolio_page/2017-가구박물관-패션쇼

Tabla 12. Análisis: gat

\begin{tabular}{|c|c|}
\hline Culturema 9 & Gat [갓]* \\
\hline Definición & $\begin{array}{l}\text { Gat, sombrero. Sombrero de ala ancha y redonda que utilizaban los hombres adultos. } \\
\text { (DDCE). }\end{array}$ \\
\hline Contexto 1 & Gat (sombrero de hombre) \\
\hline Segmentación & Gat [1] (sombrero [2] de hombre [3]) \\
\hline Técnicas utilizadas & [1] Préstamo + [2] Generalización + [3] Usuario \\
\hline
\end{tabular}

* El gat es un tipo de sombrero con ala redonda que se utilizaba entre los hombres eruditos en la dinastía Choseon (1392-1897). 


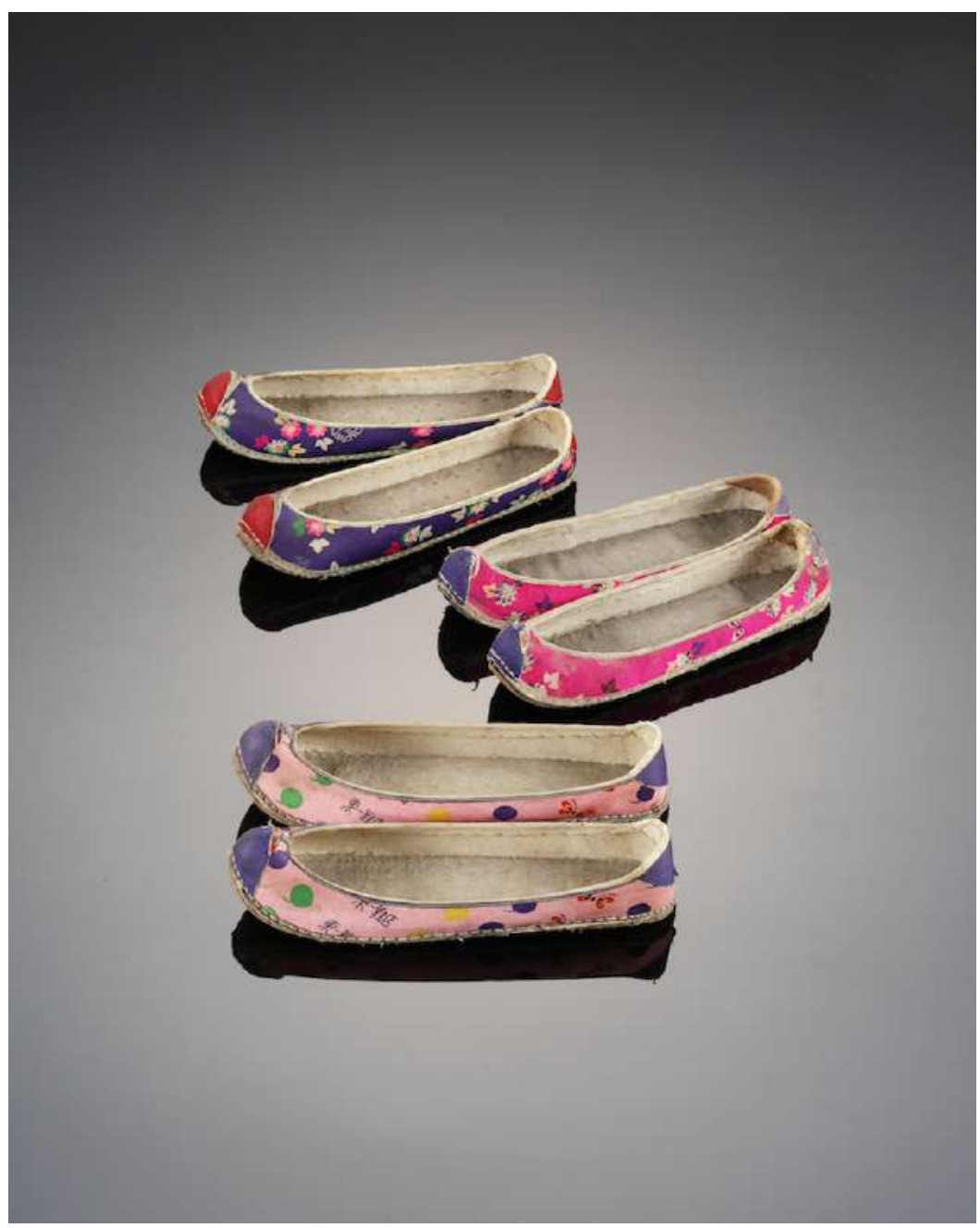

Figura 13. Kkotsin. Imagen extraída de Encyclopedia of Korean Culture of Basic Necessities. Clothing I (National Folk Museum of Korea, 2017a, p. 342).

Tabla 13. Análisis: kkotsin

\begin{tabular}{|c|c|}
\hline Culturema 10 & Kkotsin [꽃신]* \\
\hline Definición & $\begin{array}{l}\text { Kkotsin, zapatos con flores. Calzado bellamente decorado con dibujos florales o con varios } \\
\text { colores. (DDCE). }\end{array}$ \\
\hline Contexto 1 & $\begin{array}{l}\text { Kkotsin. El kkotsin es un tipo de calzado de seda con bordados de flores. Cumple un papel } \\
\text { importante para completar la elegancia del hanbok. }\end{array}$ \\
\hline Segmentación & $\begin{array}{l}\text { Kkotsin [1]. El kkotsin [1] es un tipo de calzado [2] de seda [3] con bordados [3] de flores [4]. } \\
\text { Cumple un papel importante para completar la elegancia del hanbok [5]. }\end{array}$ \\
\hline Técnicas utilizadas & [1] Préstamo + [2] Generalización + [3] Producción + [4] Aspecto + [5] Uso \\
\hline
\end{tabular}

* Kkot-significa flores y -sin es un hiperónimo que alude a cualquier tipo de calzado. En realidad, no se trataba de cualquier tipo de calzado, sino aquel que se utilizaba en ocasiones especiales; además, como se refleja en el contexto, se hacía con seda y elegantes bordados, lo que supone su uso entre la clase aristocrática y la nobleza. 


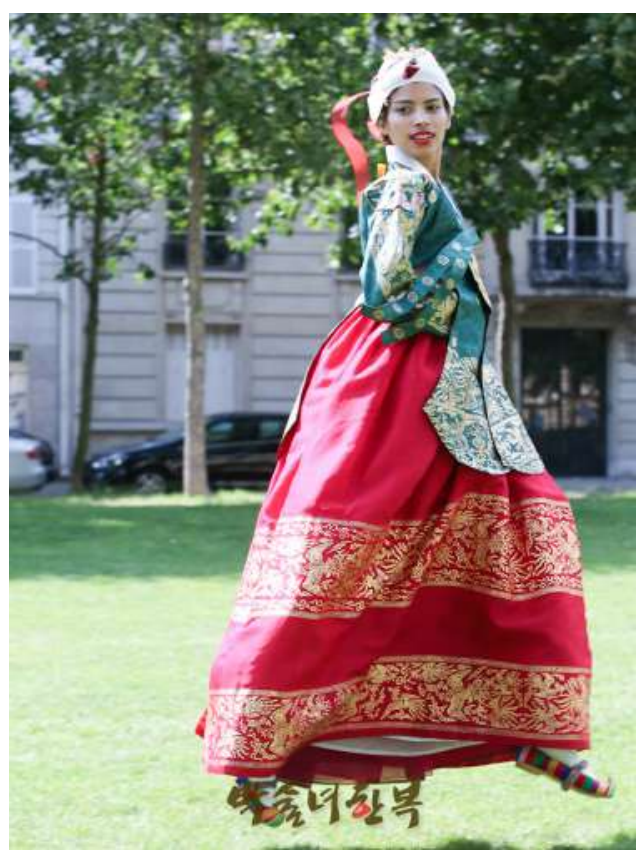

Figura 14. Chima. Imagen extraída de Park Sul Nyeo Hanbok (n. d.). Recuperado de http://www. hanbokhouse.co.kr/portfolio_page/ 프랑스-화보-38/

Tabla 14. Análisis: chima

\begin{tabular}{|c|c|}
\hline Culturema 11 & Chima [치마] \\
\hline Definición & $\begin{array}{l}\text { Falda. Prenda de vestir o parte del vestido de mujer que cae desde la cintura sin ceñirse a } \\
\text { las piernas. (DDCE). }\end{array}$ \\
\hline Contexto 1 & $\begin{array}{l}\text { La chima es la falda del hanbok de la mujer. Hay varias clases de chima: de capa simple, } \\
\text { doble y acolchada. }\end{array}$ \\
\hline Segmentación & $\begin{array}{l}\text { La chima [1] es la falda [2] del hanbok [1] de la mujer [3]. Hay varias clases de chima [1]: de } \\
\text { capa simple, doble y acolchada[4]. }\end{array}$ \\
\hline Técnicas utilizadas & [1] Préstamo + [2] Equivalente acuñado + [3] Usuario + [4] Producción \\
\hline Contexto 2 & La pul-chima es la chima con la parte de atrás plegable... \\
\hline Segmentación & La pul-chima [1] es la chima [1] con la parte de atrás plegable [2]... \\
\hline Técnicas utilizadas & [1] Préstamo + [2] Producción \\
\hline Contexto 3 & ...mientras que la tong-chima es la falda en tubo. \\
\hline Segmentación & ...mientras que la tong-chima [1] es la falda [2] en tubo [3]. \\
\hline Técnicas utilizadas & [1] Préstamo + [2] Equivalente acuñado + [3] Aspecto \\
\hline Contexto 4 & $\begin{array}{l}\text { La novia viste una chima verde (falda), un jeogori amarillo (chaqueta corta), y } \\
\text { un wonsam (el sobretodo de la novia). }\end{array}$ \\
\hline Segmentación & $\begin{array}{l}\text { La novia [1] viste una chima [2] verde [3] (falda [4]), un jeogori amarillo (chaqueta corta), y } \\
\text { un wonsam (el sobretodo de la novia). }\end{array}$ \\
\hline Técnicas utilizadas & [1] Usuario + [2] Préstamo + [3] Aspecto + [4] Equivalente acuñado \\
\hline Contexto 5 & $\begin{array}{l}\text { El hanbok de los niños se compone generalmente, de jeogori (chaqueta), chima (falda) } \\
\text { o baji (pantalones), rayado con varios colores. }\end{array}$ \\
\hline Segmentación & $\begin{array}{l}\text { El hanbok de los niños se compone generalmente, de jeogori (chaqueta), chima [1] (falda } \\
\text { [2]) o baji (pantalones), rayado con varios colores. }\end{array}$ \\
\hline Técnicas utilizadas & [1] Préstamo + [2] Equivalente acuñado \\
\hline
\end{tabular}

* Chima es una palabra común, que hasta ahora se utiliza para referirse a una falda y no implica casi ninguna dificultad para su traslación ya que existe su equivalente semántico. En los contextos, encontramos variantes pul-chima y tong-chima. 


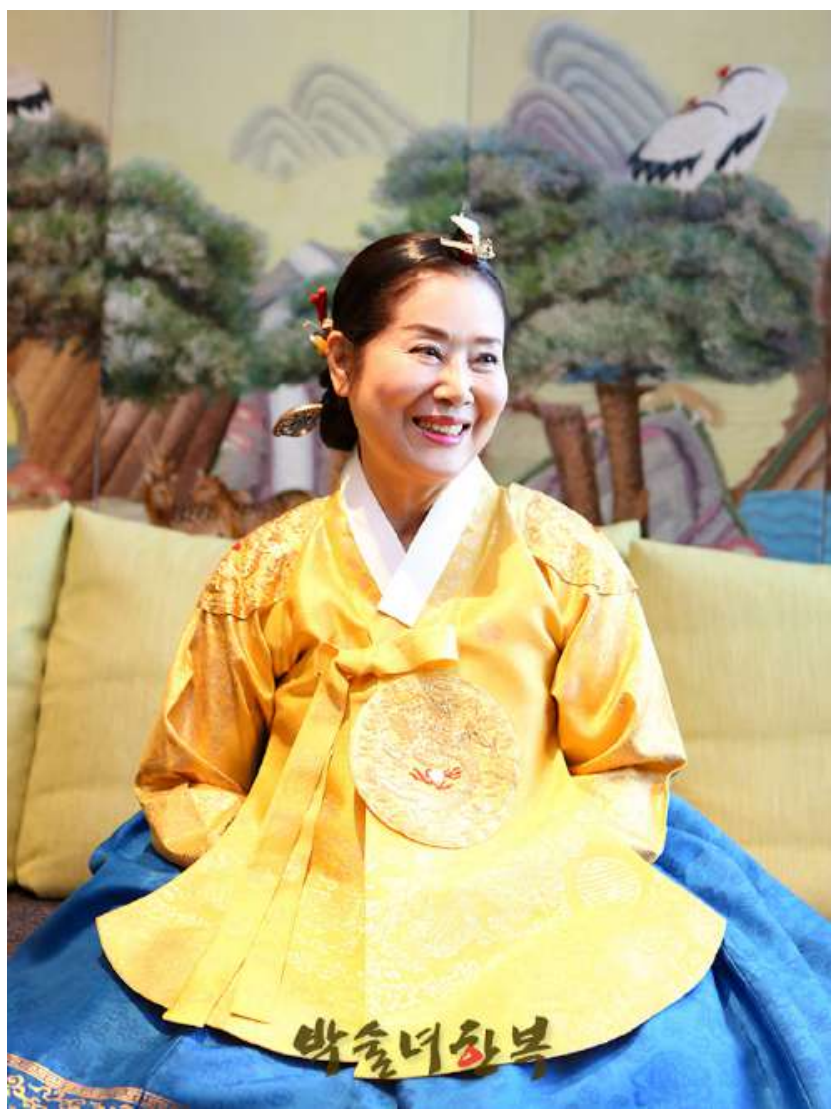

Figura 15. Dangui. Imagen extraída de Park Sul Nyeo Hanbok (n. d.). Recuperado de http://www. hanbokhouse.co.kr/portfolio_page/ 콘래드-호텔-아트리오-웨딩쇼_선우용녀-2/

Tabla 15. Análisis: dangui

\begin{tabular}{|c|c|}
\hline Culturema 12 & Dangui [당의]* \\
\hline Definición & Es una vestimenta femenina que se usa por encima de jeogori. (GDEC) [Traducción propia]. \\
\hline Contexto 1 & Las niñas suelen vestir dangui, una especie de sobretodo ceremonial. \\
\hline Segmentación & Las niñas [1] suelen vestir dangui [2], una especie de sobretodo [3] ${ }^{*}$ ceremonial [4]. \\
\hline $\begin{array}{l}\text { Técnicas } \\
\text { utilizadas }\end{array}$ & [1] Usuario + [2] Préstamo + [3] Particularización + [4] Uso \\
\hline Contexto 2 & $\begin{array}{l}\text { El hombre viste el geumgwanjobok, mientras que la mujer viste el dengui***, una clase de } \\
\text { vestido específico para ocasiones especiales. }\end{array}$ \\
\hline Segmentación & $\begin{array}{l}\text { El hombre viste el geumgwanjobok, mientras que la mujer [1] viste el dengui [2], una clase de } \\
\text { vestido [3] específico para ocasiones especiales [4]. }\end{array}$ \\
\hline $\begin{array}{l}\text { Técnicas } \\
\text { utilizadas }\end{array}$ & [1] Usuario + [2] Préstamo + [3] Generalización + [4] Uso \\
\hline
\end{tabular}

* El dangui es un suplemento que las mujeres vestían como sobretodo en algunas ceremonias importantes de la dinastía Choseon.

** Se entiende el 'sobretodo' como una particularización de 'abrigo'

*** Encontramos una errata en la web: no es dengui sino dangui 


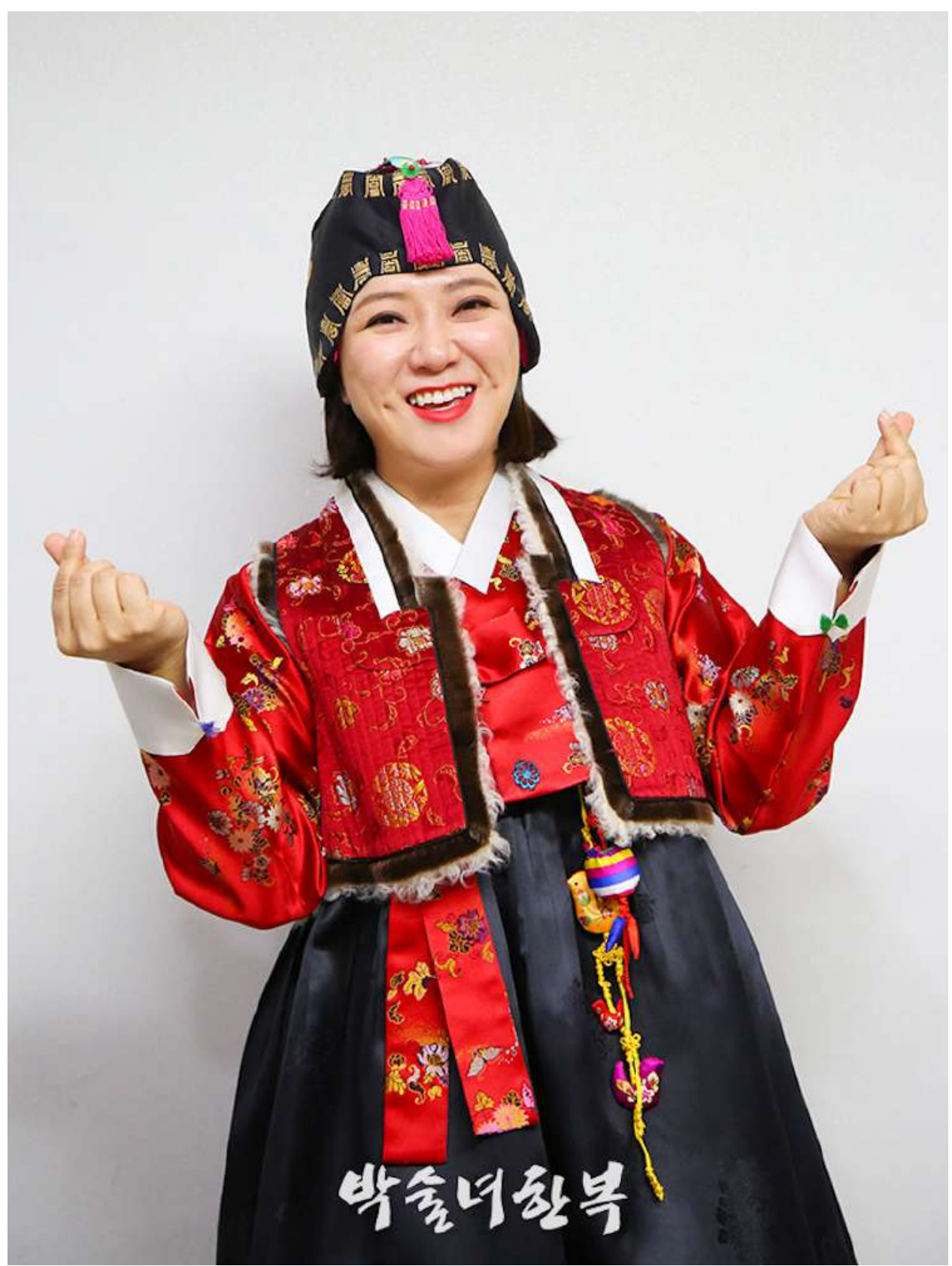

Figura 16. Joggi. Imagen extraída de Park Sul Nyeo Hanbok (n. d.). Recuperado de http://www.hanbokhouse. co.kr/portfolio_page/kbs2-사장님-귀는-당나귀-귀-4/

Tabla 16. Análisis: joggi

$\begin{array}{lll}\begin{array}{l}\text { Culturema 13 } \\ \text { Definición }\end{array} & \text { Joggi [조끼] } \\ \text { Contexto 1 } & \text { Chaleco. Prenda de vestir sin mangas que se pone encima de la camisa. (DDCE). } \\ \text { Segmentación } & \text { Joggi (chaleco) } \\ \text { Técnicas utilizadas } & \text { Joggi [1] (chaleco [2]) }\end{array}$




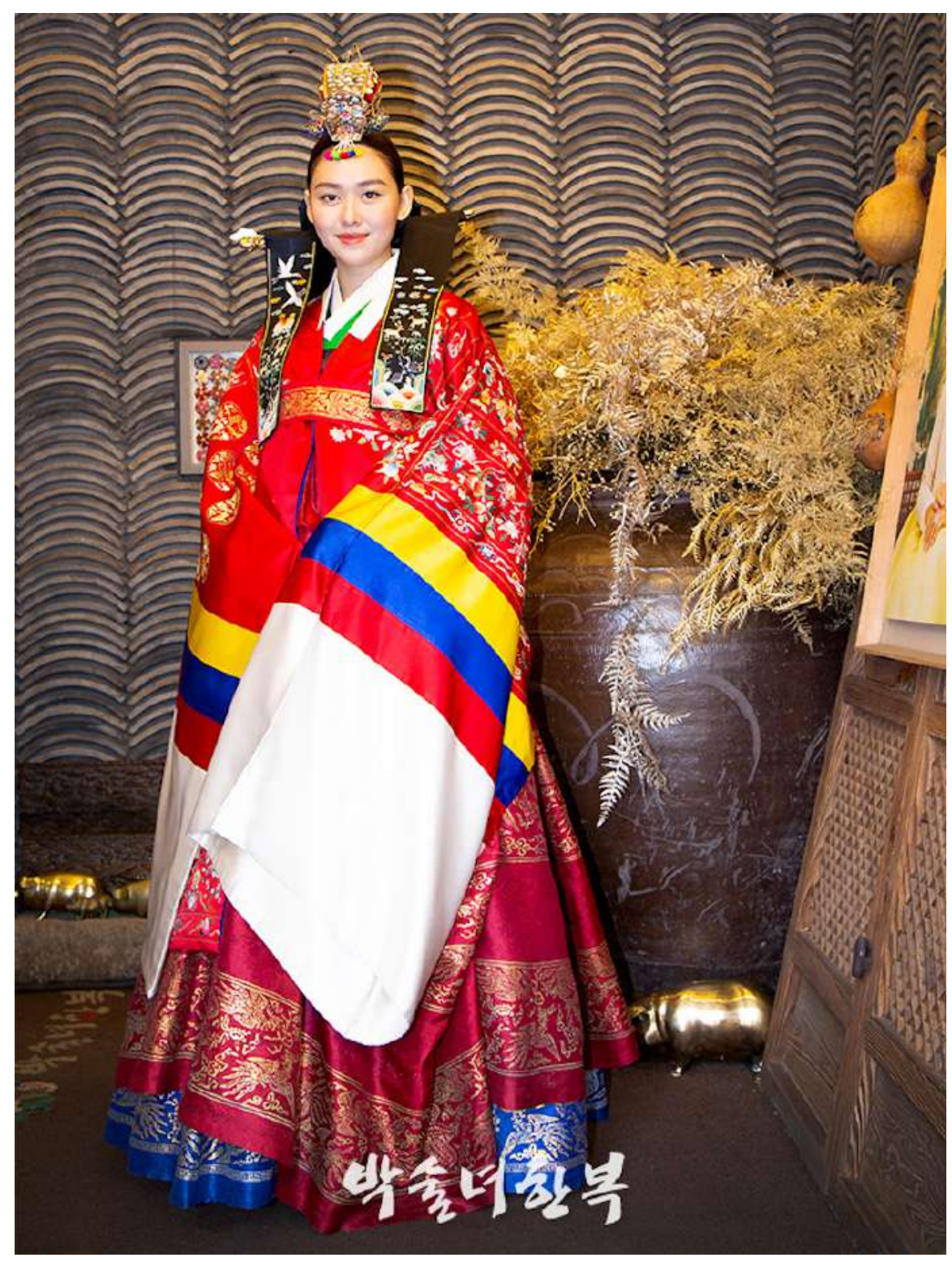

Figura 17. Wonsam. Imagen extraída de Park Sul Nyeo Hanbok (n. d.). Recuperado de http://www.hanbokhouse. co.kr/portfolio_page/미스-베트남-한복-체험-2/

Tabla 17. Análisis: wonsam

\begin{tabular}{|c|c|}
\hline Culturema 14 & Wonsam [원삼]* \\
\hline Definición & $\begin{array}{l}\text { Wonsam. Prenda del hanbok que generalmente se colocaban las novias o las mujeres de } \\
\text { alto rango en el palacio. (DDCE). }\end{array}$ \\
\hline Contexto 1 & $\begin{array}{l}\text { La novia viste una chima verde (falda), un jeogori amarillo (chaqueta corta), y } \\
\text { un wonsam (el sobretodo de la novia). }\end{array}$ \\
\hline Segmentación & $\begin{array}{l}\text { La novia viste una chima verde (falda), un jeogori amarillo (chaqueta corta), y un wonsam } \\
\text { [1] (el sobretodo [2] de la novia [3]). }\end{array}$ \\
\hline Técnicas utilizadas & [1] Préstamo + [2] Particularización + [3] Usuario \\
\hline
\end{tabular}

* Es la parte superior del vestido de la novia, el llamado cuerpo. 


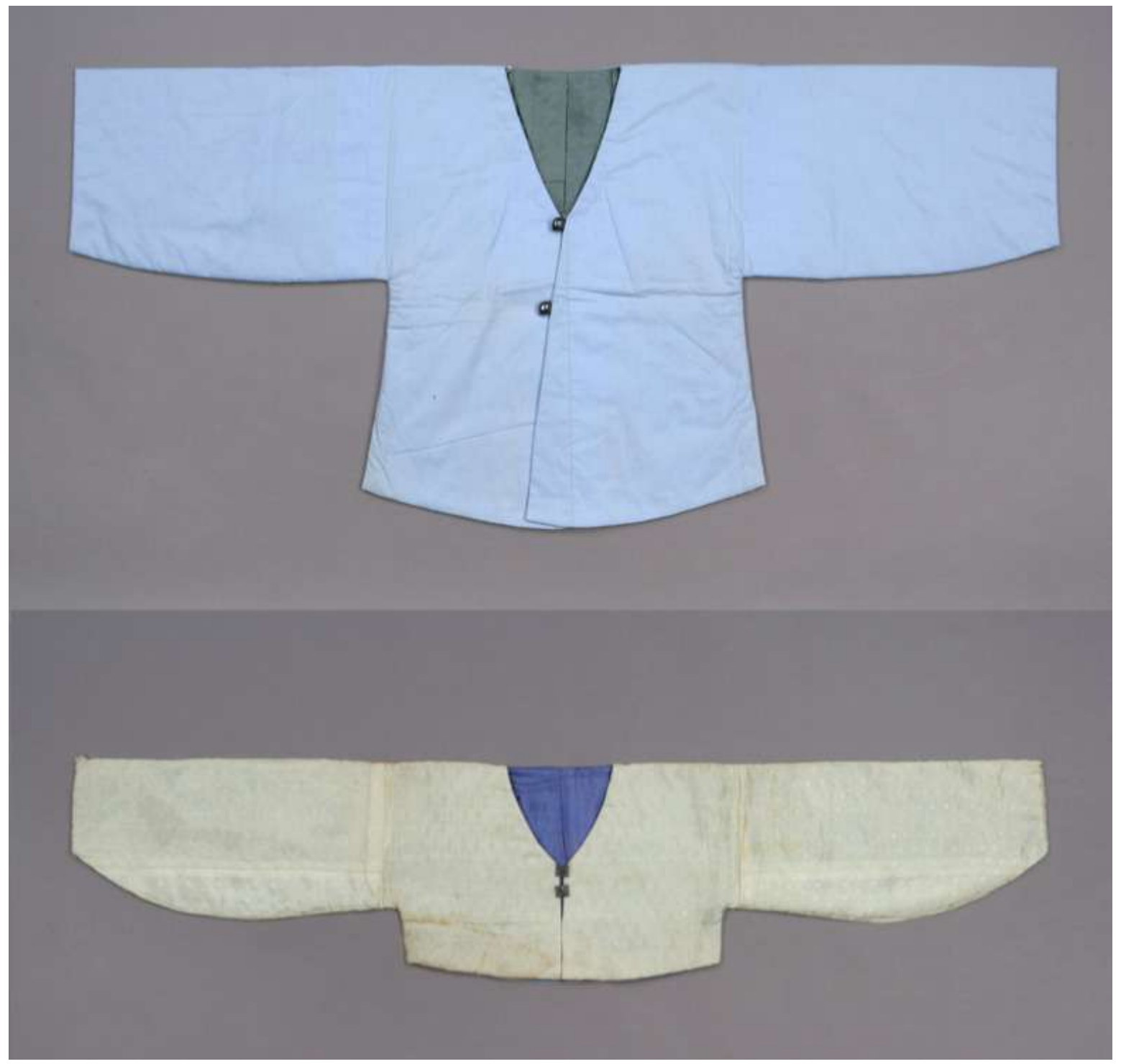

Figura 18. Magoja. Imagen extraída de Encyclopedia of Korean Culture of Basic Necessities. Clothing ॥ (National Folk Museum of Korea, 2017b, p. 782).

Tabla 18. Análisis: magoja

\begin{tabular}{|c|c|}
\hline Culturema 15 & Magoja [마고자] \\
\hline Definición & $\begin{array}{l}\text { Magoja, abrigo. Abrigo tradicional coreano sin cuello usado sobre el traje hanbok, el cual } \\
\text { se cierra con botones en lugar de cordones en ambas delanteras. (DDCE). }\end{array}$ \\
\hline Contexto 1 & $\begin{array}{l}\text { El novio viste el baji (pantalones), joggi (chaleco), el magoja (chaqueta) y el durumagi } \\
\text { (sobretodo). }\end{array}$ \\
\hline Segmentación & $\begin{array}{l}\text { El novio viste el baji (pantalones), joggi (chaleco), el magoja [1] (chaqueta [2]) y el } \\
\text { durumagi (sobretodo). }\end{array}$ \\
\hline Técnicas utilizadas & [1] Préstamo + [2] Generalización \\
\hline
\end{tabular}

Nuevas perspectivas de investigación en la traducción especializada en lenguas románicas: aspectos comparativos, léxicos, fraseológicos, discursivos y didácticos 


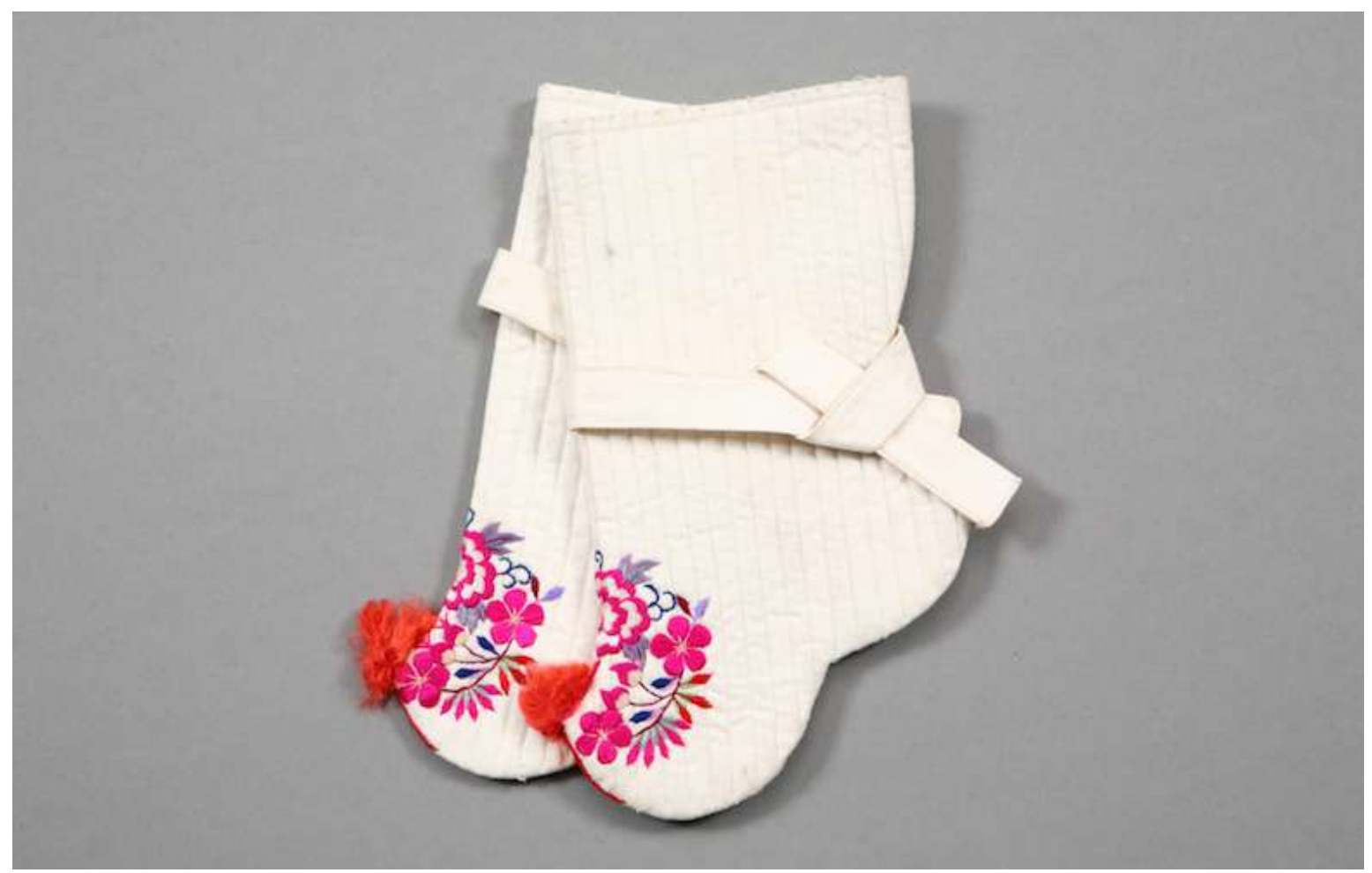

Figura 19. Beoseon. Imagen extraída de Encyclopedia of Korean Culture of Basic Necessities. Clothing ॥ (National Folk Museum of Korea, 2017b, p. 679).

Tabla 19. Análisis: beoseon

$\begin{array}{ll}\begin{array}{l}\text { Culturema 16 } \\ \text { Definición }\end{array} & \begin{array}{l}\text { Beoseon [버넌] } \\ \text { Beoseon. Prenda que se pone en los pies, como calcetines o medias. Está hecha para tener } \\ \text { una forma semejante al pie y se usa generalmente con el traje tradicional coreano hanbok. } \\ \text { (DDCE). }\end{array} \\ \begin{array}{l}\text { Beoseon. El beoseon corresponde a los actuales calcetines. En cuanto a su forma, no } \\ \text { tiene distinción entre los de los hombres y los de las mujeres, mientras que en los diseños, } \\ \text { el beoseon del hombre se caracteriza por la costura recta. }\end{array} \\ \begin{array}{l}\text { Beoseon [1]. El beoseon [1]corresponde a los actuales calcetines[2]. En cuanto a su forma, } \\ \text { no tiene distinción entre los de los hombres y los de las mujeres [3], mientras que en los } \\ \text { diseños, el beoseon [1] del hombre [3]se caracteriza por la costura recta [4]. } \\ \text { [1] Préstamo + [2] Generalización + [3] Usuario + [4] Producción }\end{array} \\ \begin{array}{l}\text { Técnicas } \\ \text { utilizadas }\end{array}\end{array}$

* El beoseon es una palabra que se refiere a las prendas que cubren los pies; en la cultura coreana ancestral los calcetines actuales no existían y utilizaban esta prenda para cumplir esa función. 


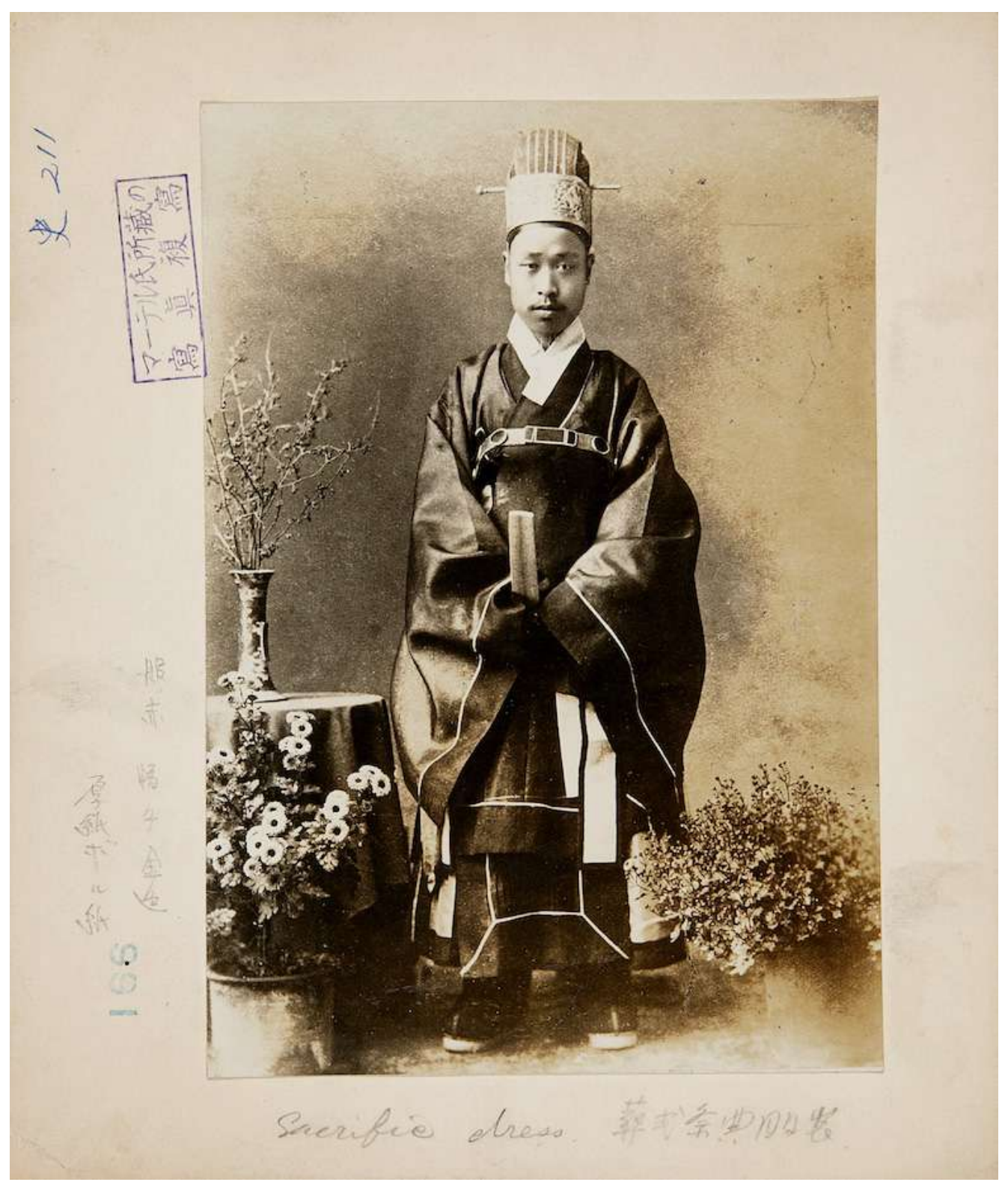

Figura 20. Geumgwanjobok. Imagen extraída de Encyclopedia of Korean Culture of Basic Necessities. Clothing ॥ (National Folk Museum of Korea, 2017b, p. 771).

Tabla 20. Análisis: geumgwanjobok

\begin{tabular}{|c|c|}
\hline Culturema 17 & Geumgwanjobok [금관조복] \\
\hline Definición & $\begin{array}{l}\text { Es una palabra que se usa para referirse al conjunto de corona dorada y traje que } \\
\text { portaban los funcionarios de alto rango. Es uno de los atuendos más nobles; se utilizaba } \\
\text { para ocasiones especiales. (GDEC) [traducción propia]. }\end{array}$ \\
\hline Contexto 1 & $\begin{array}{l}\text { El hombre viste el geumgwanjobok, mientras que la mujer viste el dengui, una clase de } \\
\text { vestido específico para ocasiones especiales. }\end{array}$ \\
\hline Segmentación & $\begin{array}{l}\text { El hombre [1] viste el geumgwanjobok [2], mientras que la mujer viste el dengui, una clase } \\
\text { de vestido específico para ocasiones especiales. }\end{array}$ \\
\hline Técnicas utilizadas & [1]Usuario + [2]Préstamo \\
\hline
\end{tabular}

Nuevas perspectivas de investigación en la traducción especializada en lenguas románicas: aspectos comparativos, léxicos, fraseológicos, discursivos y didácticos 


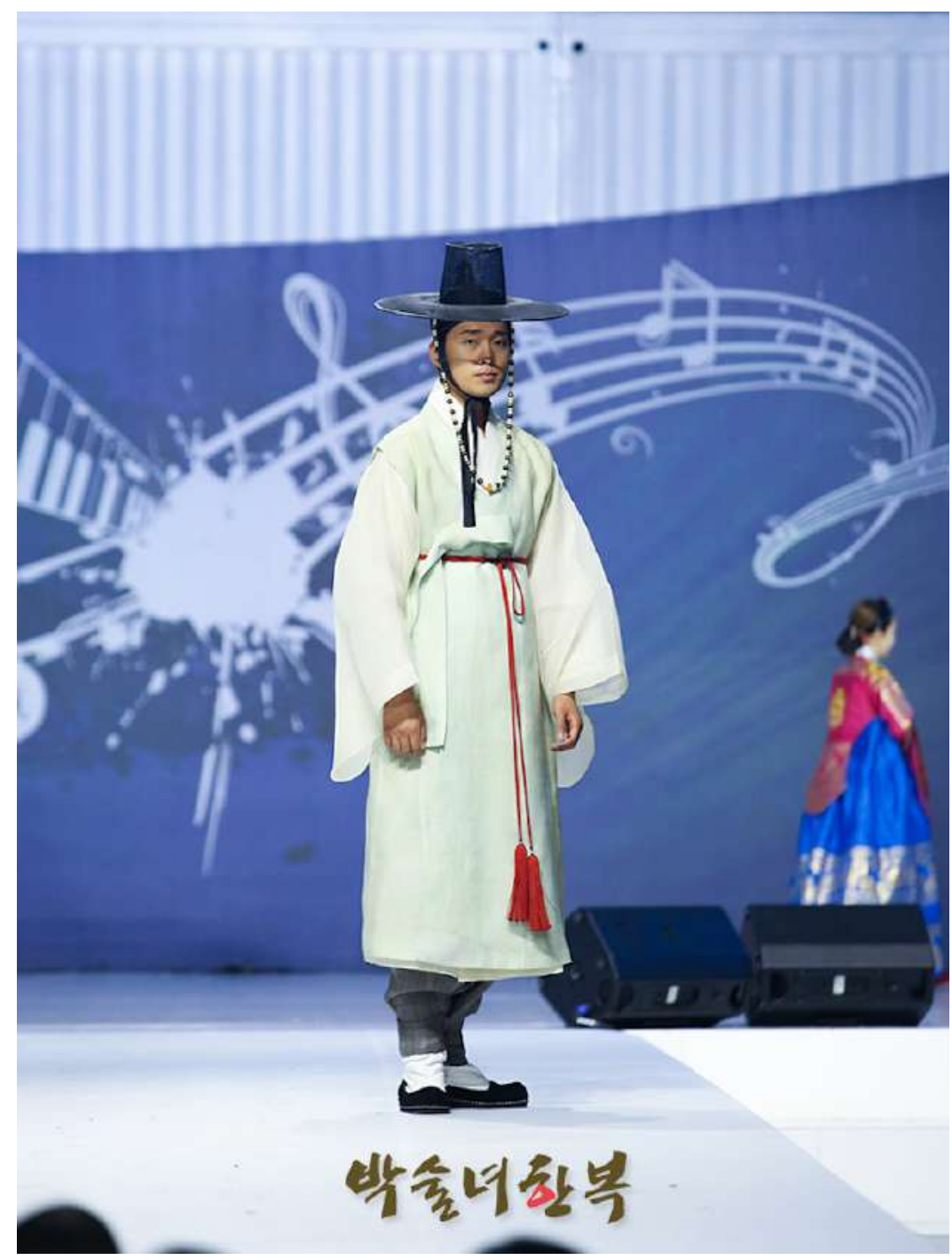

Figura 21. Durumagi. Imagen extraída de Park Sul Nyeo Hanbok (n. d.). Recuperado de http://www.hanbokhouse. co.kr/portfolio_page/asean-week-2019-패션쇼-14/

Tabla 21. Análisis: durumagi

\begin{tabular}{|c|c|}
\hline Culturema 18 & Durumagi [두루마기] \\
\hline Definición & $\begin{array}{l}\text { Hanbok (vestimenta tradicional coreana) largo que se pone cuando se sale de la casa. } \\
\text { (DDEC). }\end{array}$ \\
\hline Contexto 1 & $\begin{array}{l}\text { Durumagi. El durumagi es un abrigo que se usa en ocasiones especiales sobre la chaqueta } \\
\text { tradicional y los pantalones. }\end{array}$ \\
\hline Segmentación & $\begin{array}{l}\text { Durumagi [1]. El durumagi [1] es un abrigo [2] que se usa en ocasiones especiales [3] sobre } \\
\text { la chaqueta [2] tradicional y los pantalones [4]/[5]. }\end{array}$ \\
\hline Técnicas utilizadas & [1] Préstamo + [2] Generalización + [3] Uso + [4] Equivalente acuñado + [5] Usuario \\
\hline Contexto 2 & $\begin{array}{l}\text { El novio viste el baji (pantalones), joggi (chaleco), el magoja (chaqueta) y el durumagi } \\
\text { (sobretodo). }\end{array}$ \\
\hline Segmentación & $\begin{array}{l}\text { El novio viste el baji (pantalones), joggi (chaleco), el magoja (chaqueta) y el durumagi [1] } \\
\text { (sobretodo [2]). }\end{array}$ \\
\hline Técnicas utilizadas & [1] Préstamo + [2] Particularización \\
\hline
\end{tabular}




\section{Discusión}

Nuestro corpus, formado por 18 culturemas, cuenta con un total de 36 ocurrencias correspondientes a los contextos de uso en los que aparecen dentro de la web VisitKorea. Con respecto al número de técnicas utilizadas, se contabilizan 135, que representamos en la Tabla 22.

Tabla 22. Balance de técnicas empleadas

\begin{tabular}{|l|c|}
\hline \multicolumn{1}{c}{ Técnicas } & Frecuencia \\
\hline 1. Préstamo & 36 \\
2. Generalización & 17 \\
3. Particularización & 6 \\
4. Equivalente acuñado & 10 \\
5. Identificación de usuario & 18 \\
6. Descripción de aspecto & 16 \\
7. Descripción de información histórica & 2 \\
8. Descripción de complementos & 8 \\
9. Descripción de producción & 10 \\
10. Descripción de uso & 12 \\
Total & 135
\end{tabular}

Como podemos apreciar en los datos de la Tabla 22, la técnica que presenta una mayor recurrencia es el préstamo (36 apariciones), seguida de la identificación del usuario (18 casos), la generalización (17 veces) y la descripción de aspecto (16 ocurrencias).

Por otra parte, hemos de comentar cuántas técnicas se han utilizado de manera combinada para traducir cada unidad de contexto donde aparecen los culturemas (Tabla 23).

Tabla 23. Balance del número de técnicas utilizadas simultáneamente

\begin{tabular}{|c|c|}
\hline Combinación de técnicas & Recurrencia \\
\hline Una técnica & 0 \\
\hline Dos técnicas & 9 \\
\hline Tres técnicas & 9 \\
\hline Cuatro técnicas & 7 \\
\hline Cinco técnicas & 7 \\
\hline Seis técnicas & 2 \\
\hline Siete técnicas & 1 \\
\hline Ocho técnicas & 1 \\
\hline Total & 36 \\
\hline
\end{tabular}

Para el análisis de los culturemas de la vestimenta coreana, se han utilizado con mayor recurrencia dos o tres técnicas simultáneamente. Así, con los datos obtenidos podemos afirmar que, debido a la gran diferencia lingüística y al contraste cultural entre los países de habla hispana y Corea, resulta imprescindible, para alcanzar la eficacia comunicativa en la traslación del culturema, recurrir a distintas técnicas traslativas. Ese esfuerzo que se realiza en la traducción de estas palabras culturales da como resultado que la guía turística pueda llegar a los lectores legos o semilegos, haciendo comprensible la información que ofrece.

\section{Particularidades traductológicas de los culturemas}

En este apartado, mostramos algunas peculiaridades dignas de referir que hemos observado en el análisis de estos culturemas, a saber, aspectos textuales, marcadores de modalidad, léxico de especialidad, uso de préstamo, imprecisión léxica y aspectos diacrónicos de algunos culturemas.

\subsection{Aspectos textuales}

De acuerdo con la tipología de géneros propuesta por Calvi (2010, pp. 22-27) mediante la cual se agrupan los textos turísticos, la página web VisitKorea puede clasificarse en la familia de los textos institucionales, puesto que se trata de una guía elaborada por una entidad pública oficial con el objetivo de promocionar el destino turístico asiático. Además, este género institucional se inscribe en el macrogénero de la página web. En el plano discursivo, se clasifica como una guía descriptiva que presenta diversos subgéneros de temáticas diversificadas: arte e historia, gastronomía, artesanía, vestimenta, etc.

La sección de la página web de donde procede nuestro corpus es de naturaleza informativa ya 
que ofrece datos sobre la vestimenta tradicional del país, su historia, los eventos donde se emplea, las formas de uso, los materiales de confección, etc., a diferencia del contenido de las guías convencionales de promoción del destino, en las que se destacan las funciones directiva (Calvi y Mapelli, 2010) y conativa (Suau Jiménez y Labarta Postigo, 2017, p. 205). Con respecto a la tipología textual, se trata de un texto explicativo y descriptivo, según la propuesta de Adam (1991) y expositivo, de acuerdo con la consideración de Álvarez (2018, p. 11).

Los culturemas en los textos turísticos, aparte de la función referencial que cumplen y de representar datos propios de la idiosincrasia de una cultura o área cultural manifestada en elementos verbales, surgen para intensificar la imagen positiva de un país y, consecuentemente, despliegan un significado valorativo (Calvi, 2006, pp. 67-68; Calvi y Mapelli, 2010), un exotismo que incita al viaje e invita a vivir la experiencia cultural.

\subsection{Marcadores modalizadores}

Los culturemas de la vestimenta aparecen en la web acompañados de marcadores modalizadores, palabras o unidades sintagmáticas que realzan o intensifican los referentes. Así encontramos palabras de realce y ponderación como el verbo 'armonizar', los sustantivos 'belleza' y 'elegancia', y los adjetivos 'elegante' y 'delicado'; intensificadores que describen las características de la vestimenta tradicional y la muestran más atractiva para los lectores.

Pero, por otra parte, advertimos la tendencia a la imprecisión, la indefinición, con el empleo de los llamados hedges (Lakoff, 1973): "words whose job is to make things fuzzier or less fuzzy" (p. 47), es decir, unidades léxicas o sintagmáticas que funcionan en un texto como elementos semánticamente vagos e imprecisos que impiden el acceso a una información exacta y precisa. Así, algunos de nuestros culturemas aparecen en contextos donde surgen sintagmas como 'un tipo de' (El kkotsin es un tipo de calzado...), 'una especie de' (Las niñas suelen vestir dangui, una especie de sobretodo ceremonial) y 'una clase de' (la mujer viste el dengui, una clase de vestido específico para ocasiones especiales). De los ejemplos se colige que las palabras empleadas para el trasvase de estos culturemas han dado como resultado técnicas de generalización (calzado y vestido) y de particularización (sobretodo); se trata, pues, de palabras que no son equivalentes semánticos exactos y, en consecuencia, se utilizan para aproximarse al referente cuando no existe un equivalente acuñado.

\subsection{El léxico de especialidad}

Siguiendo a Calvi (2019, pp. 97-98), el léxico del turismo se organiza en tres grupos: léxico especializado, transversal y de la lengua general. Los culturemas pertenecen al léxico transversal, integrado por palabras específicas de los sectores relacionados con el turismo, como el arte, la historia, la gastronomía, la arquitectura, etc. (Calvi, 2019, p. 98): por tanto, los culturemas del ámbito turístico no tienen identidad propia, no se identifican con el sector turístico más que de una manera tangencial, dado que proceden de sectores y áreas de conocimiento que vierten sus léxicos particulares al constructo híbrido del léxico del turismo. No obstante, los culturemas pasan al léxico de la lengua general, debido a la íntima relación entre las palabras culturales y la cultura popular u operativa. En este sentido, los culturemas que conforman nuestro corpus son términos o léxico especializado perteneciente a un sector determinado - el de la vestimenta- $y$, simultáneamente, al léxico de la lengua general en el coreano actual. 
Sin embargo, hemos detectado algunos culturemas que resultan complejos de delimitar. Es el caso de, por ejemplo, donjeong ('tira blanca y dura para el cuello de la camisa del hanbok'), baerae ('curva de las mangas de hanbok'), dangui ('sobretodo femenino para eventos ceremoniales'), wonsam ('sobretodo femenino para la ceremonia nupcial') y magoja ('un tipo de chaqueta que se utiliza para protegerse del frío'). Se trata de culturemas raramente empleados hoy día y limitados exclusivamente a los discursos de especialidad de los sectores de la producción textil o de la historia del arte. Este fenómeno tiene que ver con el uso actual de esta vestimenta: pese a su larga tradición, se restringe su empleo a eventos especiales o festividades nacionales. Como consecuencia, estos culturemas van perdiendo su naturaleza de pertenencia a la cultura popular y van dejando de ser conocidos por los hablantes; de modo que hoy día su adquisición por parte del nativo exige de una instrucción particular.

\subsection{Tratamiento del préstamo}

Según hemos constatado, el préstamo es la técnica traslativa empleada con más recurrencia para mostrar el significado de los culturemas de la vestimenta; para ello el culturema se traslada directamente a la lengua meta (Hurtado Albir, 2018, p. 271). En nuestro caso, no aparece ningún préstamo puro, es decir, aquel cuyo significante está representado por grafias coreanas, sino que todos los culturemas aparecen transcritos al inglés. En cuanto a su tratamiento, podemos destacar, en primer lugar, que se ha utilizado la letra cursiva para la transcripción fonética de estos culturemas. En segundo lugar, hemos de atender al uso de los artículos - clases de palabras inexistentes en coreano-, y más en concreto, a la concordancia nominal: hemos constatado que a todos los culturemas, una vez tomados como préstamos en español, se les asigna el artículo definido masculino 'el' o 'los', a excepción del culturema chima (falda) que va precedido del femenino 'la' - "La chima es la falda del hanbok de la mujer"- Este hecho se debe a la terminación mayoritaria en -o que presentan los préstamos y que subordina el empleo del masculino, y la terminación en -a de chima que se combina con el femenino; además, esta voz, al equivaler a 'falda', refuerza el uso como sustantivo femenino. No obstante, esta filiación no se mantiene en todos los casos ya que, por ejemplo, el culturema jeogori, cuya traducción es mediante el sustantivo femenino 'chaqueta', lleva el artículo 'el': el jeogori. Por tanto, el género parece venir determinado más por la terminación del préstamo que por la traducción al español.

\subsection{Falta de precisión léxica}

Las técnicas relacionadas con la precisión léxica son el equivalente acuñado, la generalización y la particularización. El primero hace referencia, en el plano léxico, a la adopción de términos, palabras o traducciones reconocidas, razón por la cual no implica dificultad para su traducción. Entre tanto, la generalización es una técnica consistente en la selección de hiperónimos. Por el contrario, la particularización se basa en el empleo de palabras más precisas o hipónimos (Soto Almela, 2014, pp. 110 y 112). En nuestro corpus se encuentran culturemas traducidos siguiendo estas dos técnicas: ejemplos de generalización son chaqueta (jeogori y magoja), vestido (dangui), abrigo (durumagi) y calzado (kkotsin); en cuanto a la particularización, tenemos sobretodo (dangui y durumagi). Como se observa, para la traducción de durumagi se han utilizado las voces abrigo y sobretodo, y para dangui, vestido y sobretodo. Esto nos lleva a concluir que no existe en español un equivalente exacto para las dos voces coreanas anteriores. La traducción como abrigo o vestido es una generalización, 
mientras que sobre todo es una particularización. Como soluciones a este problema podrían emplearse la adaptación y la traducción explicativa en el plano traductológico y otros recursos extralingüísticos, como vídeos o fotografías, dependiendo del soporte y del género del texto (guía convencional, guías prácticas y guías digitales, etc.).

\subsection{Un apunte diacrónico}

Beoseon (Tabla 19), cuyo significado actual es 'calcetines tradicionales', es un cultismo. ${ }^{16}$ Originalmente significaba, según el Gran diccionario estándar de coreano, 'prenda hecha de hilo o tejido para arropar los pies desnudos' ${ }^{\prime 17}$ y la palabra de origen chino era mal (襪/말). Cuando se introdujeron en Corea los calcetines actuales, los denominaron yangmal (洋襪/ 양말). Yang- significa occidental y -mal, como hemos dicho, prenda para los pies, lo que supone que es una palabra compuesta que significa calcetines occidentales. ${ }^{18}$ Así pues, podemos indicar que la palabra yangmal (calcetines occidentales) tienen motivación semántica o es una palabra transparente, ya que su significado surge de la suma de los significados particulares de los dos elementos del compuesto. Por tanto, beoseon era la voz con la que se denominaba cualquier tipo de prenda para los pies, si bien con la generalización del uso de los calcetines occidentales, se perdió el rasgo semántico occidental. Así en la actualidad, yangmal hace referencia a 'calcetines' y el beoseon, a los 'calcetines

16 En coreano esta clase de palabras se denomina 순 우리말 (sunurimal y nuestra habla pura [traducción literal]).

17 Traducción propia.

18 En coreano se agregaba este prefijo yang-para formar palabras compuestas y denominar nuevos objetos. Constatamos así la tesis de Ullmann (1976 [1965], pp. 104-105) para quien las palabras compuestas generalmente tienen una motivación morfológica. tradicionales que se portan con la vestimenta típica coreana'. Según A. Mille (citado en U11mann, 1976, pp. 219-220), este fenómeno consiste en un cambio de significado basado en el factor de pérdida de motivación. Guiraud (1976, pp. 76-77), lo denomina oscurecimiento de la motivación etimológica, que causa el debilitamiento del sentido de la mayoría de las palabras. En este caso, de igual modo, se oscurece el rasgo semántico yang (occidental), que se consolida como una palabra simple y única. Por su parte, beseon sufrió una restricción de sentido, ya que únicamente se refiere actualmente a los calcetines tradicionales $o$ con forma similar a ellos. Asimismo, se produce un cambio en la relación semántica hiperónimo-hipónimo, ya que, si al principio beoseon era el hiperónimo y los calcetines (yangmal) el hipónimo, con el paso del tiempo se ha producido una inversión, dado que los calcetines se han convertido en el hiperónimo y el beoseon, en el hipónimo.

\section{Conclusiones}

La página web VisitKorea despliega una amplia variedad de información turística funcional básica sobre Corea del Sur y su cultura. Gracias a su carácter divulgativo y su estructura discursiva - descriptiva e informativa-, aquellos lectores legos o semilegos podrán aproximarse y entender, al menos someramente, la cultura coreana. Un espacio destacado lo constituye la vestimenta tradicional coreana que, a pesar de que con el paso del tiempo ha visto limitado su uso cotidiano, se mantiene como un referente, un símbolo de esta cultura ancestral empleado en ocasiones especiales. El conjunto de atuendos típicos de Corea refleja una larga tradición histórica que representa la identidad cultural de este país asiático y, más allá de poseer un incuestionable valor histórico-artístico, está íntimamente relacionado con la cultura popular, con el sentir 
del pueblo. En la realización de este trabajo hemos constatado el peso de la idiosincrasia cultural manifestada en las referencias que se emplean para designar este traje singular y sus respectivos complementos; especialmente, la distancia cultural entre los atuendos coreanos e hispánicos supone una dificultad, un escollo para la traducción. Para superarlo y como resultado de la investigación, hemos comprobado que el traductor encuentra en el empleo de paráfrasis explicativas una solución eficaz para el trasvase de las palabras culturales o culturemas del coreano al español. Al contrario, otras técnicas traslativas, como la generalización o la particularización, pueden generar confusiones, al no existir una equivalencia plena entre los referentes.

Así pues, con este trabajo hemos contribuido a demostrar una vez más que la traducción y la interpretación van más allá de simple traspaso verbal; son labores complejas que requieren conocimiento lingüístico y entendimiento intercultural entre la lengua y la cultura de partida y de destino.

Aún son escasos los estudios centrados en el lenguaje del turismo desde el ámbito de la traductología coreano-español y de la lingüística, y no se ha abordado por el momento investigaciones sobre la traducción cultural en otras áreas como la arquitectura, la música, las festividades y tradiciones, etc. Con esta aportación avanzamos en la línea de trabajo dedicada a los culturemas en su traducción al español, que esperamos continuar en futuras investigaciones orientándola hacia campos inexplorados.

\section{Referencias}

Adam, M. (1991). Une typologie d'inspiration bakhtinienne: penser l'hétérogéneité textualle. ÉLA, 83, 7-17.
Aixelá, J. F. (1996). Culture-specific items in translation. En R. Álvarez y M. Vidal (Ed.), Translation, power, subversion (pp. 52-78). Multilingual Matters. https://doi.org/10.14198/ raei.1996.9.13-4

Álvarez, M. (2018). Tipos de escrito II: Exposición y argumentación (9. ${ }^{\text {Ed. }}$.). Arco Libros.

Ayuso Collante, C. (2019). Léxico patrimonial. Culturemas palentinos. Revista de Folklore, 445, 3-30.

Baker, M. (2011). In other words: A coursebook on translation. (2. ${ }^{\mathrm{a}}$ Ed.). Routledge. https://doi. org/10.4324/9780203832929

Calvi, M. V. (2006). Lengua y comunicación en el español del turismo. Arco Libros.

Calvi, M. V. (2010). Los géneros discursivos en la lengua del turismo una propuesta de clasificación. Ibérica: Revista de la Asociación Europea de Lenguas para Fines Específicos (AELFE), 19, 9-32.

Calvi, M. V. (2018). El lenguaje del turismo. En M. V. Calvi, C. Bordonaba y G. Mapelli (Ed.), Las lenguas de especialidad en español (pp. 199224) (reimpresión de la obra original publicada en 2009). Studi Superiori.

Calvi, M. V. (2019). Léxico del turismo y lexicografía. En M. C. Cazorla Vivas, M. A. García Aranda y M. P. Nuño Álvarez (Ed.), Lo que hablan las palabras. Estudios de lexicología, lexicografia y gramática en honor de Manuel Alvar Ezquerra (pp. 97-109). Axac.

Calvi, M. V. y Mapelli, G. (2010). La presencia de términos culturales en las páginas web de turismo. En P. Civil y F. Crémoux (Eds.), Nuevos caminos del hispanismo. Asociación Internacional de Hispanistas (pp. 43-51). Iberoamericana.

Campos Martín, N. (2011). La traducción de textos especializados: análisis traductológico del término "bail" y del término "contrat". Anales de Filología Francesa, 19, 41-61. https://doi. org/10.6018/analesff

Cruces Roldán, C. (2005). El flamenco como objeto de deseo. Autenticidad, mercado y políticas culturales. PH Cuadernos, 17, 142-155.

Galisson, R. (1988). Cultures et lexicultures. Pour une approche dictionnairique de la culture partagée. Annexes de Cahiers de linguistique hispanique médiévale, Hommage à Bernard Pottier, 7(1), 325-341. https://doi.org/10.3406/ cehm.1988.2133 
Galisson, R. (2000). La pragmatique lexiculturelle pour acceder autrement, à une autre culture, par un autre lexique. Melange CRAPEL, 25, 4773.

González-Pastor, D. M. (2018). ¿Cómo se traducen los culturemas del ámbito turístico? Análisis de estrategias de traducción (español-inglés). Comares.

Guiraud, P. (1976). La semántica (H. Hasler, Trad.). (2. ${ }^{a}$ Ed.). Fondo de Cultura Económica.

Hatim, B. y Mason, I. (1995). Teoría de la traducción: una aproximación al discurso (S. Peña, Trad.). Ariel Lenguas Modernas.

Hernández i Martí, M. (2005). La memoria construida. Patrimonio cultural y modernidad. Tirant Lo Blanc.

Hurtado Albir, A. (2018). Traducción y traductología. Introducción a la traductología. (10.a Ed.). Cátedra. https://doi.org/10.24310/ TRANS.1996.v0i1.2286

Kim, H. (2016). A design of Spanish translation teaching for undergraduate education: Application of the functionalist theory of translation. Estudios Hispánicos, 81, 55-84. https:// doi.org/10.21811/EH.81.55

Korea Tourism Organization. [sitio web] https:// spanish.visitkorea.or.kr/spa/index.kto\#

Kwon, E. H. (2009). La traducción de los culturemas coreano-español. The Comparative Study of World Literature, 28, 427-462. https://www. dbpia.co.kr/Journal/articleDetail?nodeId=NODE08817506\#

Lakoff, G. (1973). Hedges: A study in meaning criteria and the logic of fuzzy concepts. Journal of Philosophical Logic, 2, 458-508. https://doi. org/10.1007/BF00262952

Le Gall, E. (2009). La lexiculture dans le dictionnaire québécois d'aujourd'hui (1992) de JeanClaude Boulanger: étude des lettres A et B. ÉLA: Études de linguistique appliquée, 154, 177189. https://doi.org/10.3917/ela.154.0177

Luque Nadal, L. (2009). Los culturemas: ¿unidades lingüísticas, ideológicas o culturales? Language Design, 11, 93-120. http://elies.rediris.es/Language_Design/LD11/LD11-05-Lucia.pdf

Marlowe, M. (enero, 2012). Against the theory of 'dynamic equivalence'. http://www.bible-researcher.com/dynamic-equivalence.html

Mayoral Asensio, R. (1999). La traducción de referencias culturales. Sendebar, 10/11, 67-88.
Mayoral Asensio, R. y Muñoz Martín, R. (1997). Estrategias comunicativas en la traducción intercultural. En P. Fernández Nistal y J. M. Bravo Gonzalo (Coord.), Aproximaciones a los estudios de traducción (pp. 143-192). Servicio de Apoyo a la Enseñanza de la Universidad de Valladolid.

Mendoza García, I. (2018). Unidades de traducción culturalmente marcadas: propuesta de clasificación dinámica con fines traductológicos. Hermes: Journal of Language and Communication in Business, 58, 193-213. https://doi. org/10.7146/hjlcb.v0i58.111685

Molina Martínez, L. (2006). El otoño del pingüino. Análisis descriptivo de la traducción de los culturemas. Publicacions de la Universitat Jaume I.

Molina Martínez, L. y Hurtado Albir, A. (2002). Translation techniques revisited: A dynamic and functionalist approach. Méta, 47(4), 498512. https://doi.org/10.7202/008033ar

Newmark, P. (2010). Manual de traducción (V. Moya, Trad.). (6. ${ }^{a}$ Ed.). Cátedra.

Nida, E. (1945). Linguistics and ethnology in translation-problems. Word, 1, 194-208. https:// doi.org/10.1080/00437956.1945.11659254

Nord, C. (1994). It's tea-time in Wonderland: Culture-markers in fictional texts. En H. Pürsche et al. (Eds.), Intercultural Communication (pp. 523-538). Peter Lang.

Nord, C. (2007). Translating as a purposeful activity. Functionalist approaches explained (reimpresión de la obra original publicada en 1997). St. Jerome Publishing. https://doi. org/10.4324/9781351189354

Park, S., Ryu, M. y Jun, J. (2019). The effect of hanbok experience marketing on customer satisfaction and revisit intention. Journal of the Korean Data Analysis Society, 21(3), 1425-1437. https://doi.org/10.37727/jkdas.2019.21.3.1425

Roberts, J. H. (1974). Dynamic equivalence in bible translation. Neotestamentica, 8(1), 7-20. https:// hdl.handle.net/10520/AJA2548356_14

Robles Ávila, S. (2019a). Ciudades en la Red, redes de ciudades: arquitectura formal y caracterización lingüístico-discursiva de las páginas web de ciudades patrimonio de la humanidad españolas. En E. Baena Peña (Coord.), Visiones 
literarias y lingüísticas del paisaje urbano (pp. 73111). Marcial Pons. https://doi.org/10.2307/j. ctv10rrcw9.7

Robles Ávila, S. (2019b). Estrategias publicitarias en la configuración discursiva de las páginas web de ciudades patrimonio de la humanidad españolas. En Á. Cervera, y H. García-Cervigón (Ed.), Análisis del discurso en el español contemporáneo (pp, 175-192). Visor.

Robles Ávila, S. y Park, J. S. (2021). Culturemas y patrimonio: el caso de los términos culturales gastronómicos en coreano y su tratamiento lexicográfico en español. En A. Pérez Jiménez (Ed.), Patrimonio filológico. Contribuciones y nuevas perspectivas (pp. 75-91). Peter Lang. https://doi.org/10.3726/b17577

Soto Almela, J. (2014). Los términos culturales en el ámbito turístico español-inglés: traducción, manipulación y recepción real en usuarios anglófonos (Tesis doctoral). Universidad de Murcia, España. https://www.tdx.cat/handle/10803/284770

Stolze, R. (2011). Übersetzungstheorien (U. Im et al., trad.). Hankuk University of Foreign Studies Press.

Suau Jiménez, F. y Labarta Postigo, M. (2017). El discurso interpersonal en la guía turística en español y alemán y su importancia para la traducción. Normas: revista de estudios lingüísticos hispánicos, 7(1), 204-223. https://doi. org/10.7203/Normas.7.10441

Ullmann, S. (1976). Semántica. Introducción a la ciencia del significado (J. Ruiz-Werner, Trad.) (reimpresión de la obra original publicada en 1965). Aguilar.

UNESCO (2003). Convención para la Salvaguardia del Patrimonio Cultural Inmaterial. UNESCO.

Waard, J. D. y Nida, E. (1986). From one language to another: Functional equivalence in Bible translating. Thomas Nelson.

\section{Diccionarios}

Intituto Nacional de la Lengua Coreana [n. d.]. Diccionario didáctico coreano-español del Instituto Nacional de la Lengua Coreana. https://krdict. korean.go.kr/spa/mainAction?nation=spa

Intituto Nacional de la Lengua Coreana [n. d.]. Gran diccionario estándar de coreano del Instituto Nacional de la Lengua Coreana. (traducción literal de 국립국어원 표준국어대사전). https:// stdict.korean.go.kr/main/main.do

Real Academia Española — RAE- (2014). Diccionario de la lengua española, 23. ${ }^{a}$ ed., [versión 23.4 en línea]. https://dle.rae.es

\section{Fotografías}

National Folk Museum of Korea (2017a). Encyclopedia of Korean Culture of Basic Necessities. Clothing I. National Folk Museum of Korea

National Folk Museum of Korea (2017b). Encyclopedia of Korean Culture of Basic Necessities. Clothing II. National Folk Museum of Korea

Park Sul Nyeo Hanbok. (n. d.). http://www.hanbokhouse.co.kr/

Cómo citar este artículo: Robles Ávila, S. y Park, J. S. (2021). Traducción de culturemas en textos turísticos: tratamiento en español de las voces que designan la vestimenta tradicional coreana. Mutatis Mutandis, Revista Latinoamericana de Traducción, 14(2), 307-344. https://doi. org/10.17533/udea.mut.v14n2a03 